\title{
Synthesis and Characterization of Chimeric 2-5A-DNA Oligonucleotides
}

This unit describes the synthesis of chimeric oligonucleotides in which the small $\left(2^{\prime}-5^{\prime}\right)$ oligoriboadenylate activator of RNase $\mathrm{L}$ is covalently joined through a butanediol phosphate linker to a deoxyribooligonucleotide (Fig. 4.4.1). The products are termed "2-5A-antisense" when the deoxyribonucleotide portion of the chimera is targeted against a specific RNA. The overall synthetic strategy (see Basic Protocol 1) is based on the phosphite-triester approach to DNA/RNA synthesis (UNITS 3.3 \& 3.5). Appropriately protected 2-cyanoethylphosphoramidite derivatives of adenosine, the butanediol linker, and the usual four deoxyribonucleosides are used for chain elongation, and the solid-phase methodology is employed with protected deoxyribonucleosides covalently linked to controlled-pore glass (CPG) through a long-chain alkyl amine (lcaa) and a succinyl moiety. 5'-Phosphorylation of the chimera completes the basic synthesis. After deprotection, the chimera is purified (see Basic Protocol 2) and characterized by a number of independent methods (see Basic Protocols 2 to 4). Two Support Protocols describe the synthesis of the central building block for the 2-5A domain of 2-5A-antisense oligonucleotide (see Support Protocol 1) and preparation of the synthon for the linker between 2-5A and the antisense oligonucleotide (see Support Protocol 2).

CAUTION: When working with radioactivity, take appropriate precautions to avoid contamination of the experimenter and the surroundings. Carry out the experiment and dispose of wastes in an appropriately designated area, following the guidelines provided by the local radiation safety officer.

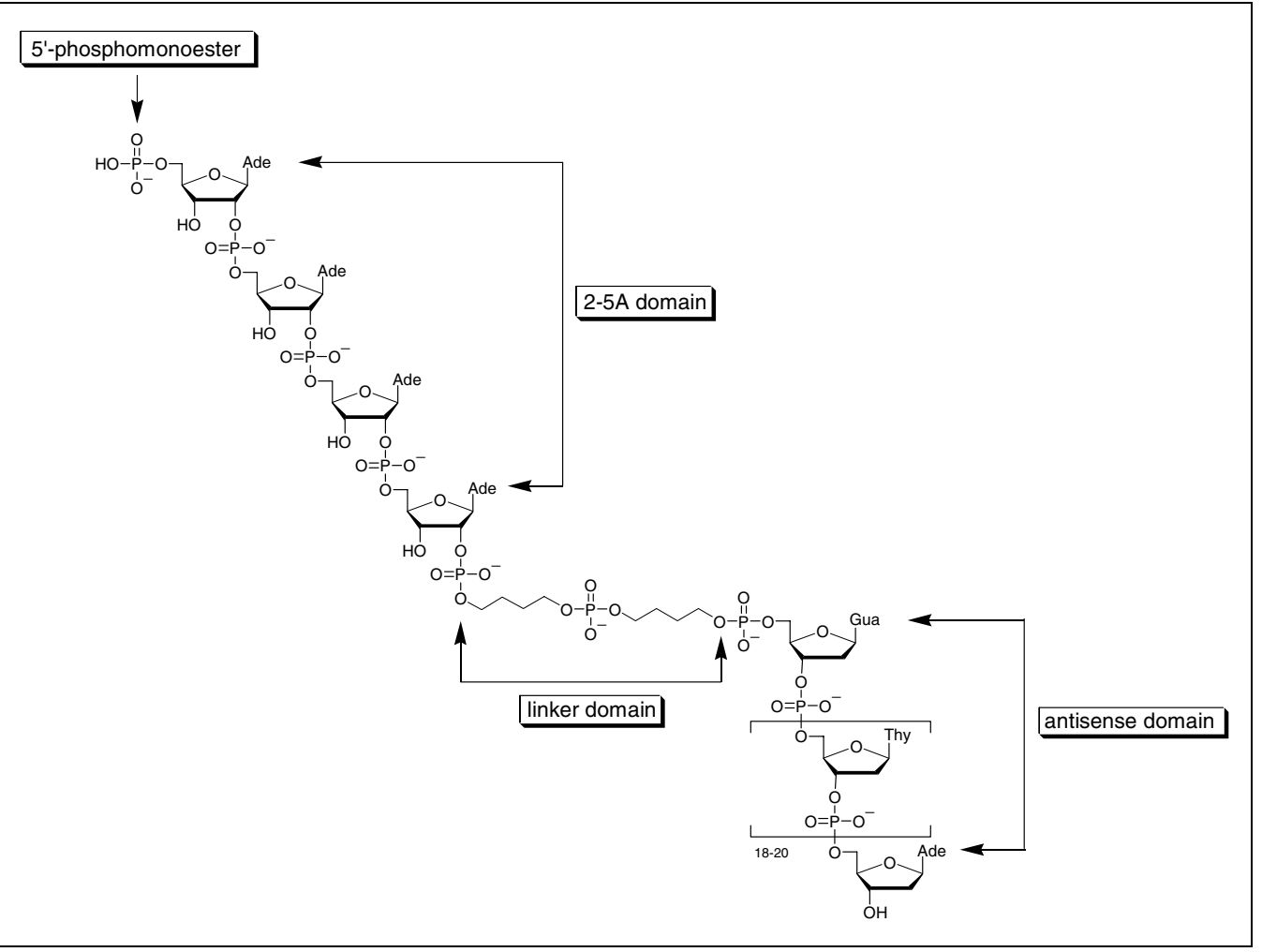

Figure 4.4.1 General structure of 2-5A-antisense oligonucleotides. 


\section{BASIC PROTOCOL 1 \\ AUTOMATED SYNTHESIS OF CHIMERIC 2-5A-ANTISENSE OLIGONUCLEOTIDES ACCORDING TO SOLID-PHASE PHOSPHORAMIDITE CHEMISTRY}

The standard 2-5A-antisense chimera has four regions (Fig. 4.4.1): (1) antisense DNA, (2) linker dimer, (3) 2-5A tetramer, and (4) $5^{\prime}$-terminal phosphate monoester. This procedure describes construction of the antisense domain, coupling of the butanediol linkers, addition of the $\left(2^{\prime}-5^{\prime}\right)$-oligoriboadenylate domain, and $5^{\prime}$-phosphorylation. Details are given for two different automated ABI DNA synthesizers. 5'-O-Solid supports from $\mathrm{ABI}$ are used and are listed below; $3^{\prime}$-O-Solid supports from Glen Research are also listed, and are used to synthesize oligonucleotides with terminal $\left(3^{\prime}-3^{\prime}\right)$-phosphodiester bonds.

\section{Materials}

Reagents for oligonucleotide synthesis: Acetonitrile $\left(\mathrm{CH}_{3} \mathrm{CN}\right.$; diluent; Cruachem) Tetrazole/acetonitrile (activator/coupling solution; PE Biosystems) Acetic anhydride/lutidine/tetrahydrofuran (capping solution; PE Biosystems) $\mathrm{N}$-Methylimidazole/tetrahydrofuran (capping solution; PE Biosystems) Trichloroacetic acid/ $\mathrm{CH}_{2} \mathrm{Cl}_{2}$ (detritylation solution; PE Biosystems) Iodine $/ \mathrm{H}_{2} \mathrm{O} /$ pyridine/tetrahydrofuran (oxidizer; $\mathrm{PE} \mathrm{Biosystems)}$ Tetraethylthiuram disulfide (TETD)/ $\mathrm{CH}_{3} \mathrm{CN}$ (PE Biosystems; for sulfurization)

$0.1 \mathrm{M}$ phosphoramidite solutions (see recipe):

Linker CE phosphoramidite: 4- $O$-(4,4'-dimethoxytrityl)oxybutyl-1[(2-cyanoethyl)- $N, N$-diisopropylphosphoramidite] (see Support Protocol 2) RNA CE phosphoramidite (2-5A): $N^{6}$-benzoyl-5'-O-(4,4'-dimethoxytrityl)$3^{\prime}$-O-(tert-butyldimethylsilyl)adenosine-2'-(N,N-diisopropyl-2cyanoethyl)phosphoramidite (see Support Protocol 1)

Phosphorylation reagent: 2-[2-(4,4'-Dimethoxytrityl)ethylsulfonyl]ethyl(2-cyanoethyl)- $N, N$-diisopropylphosphoramidite $5^{\prime}$-O-Dimethoxytrityl- $N^{6}$-benzoyl-2'-deoxyadenosine-3'(2-cyanoethyl- $N, N$-diisopropyl)phosphoramidite $\left(\mathrm{dA}^{\mathrm{Bz}}\right)$ $5^{\prime}$-O-Dimethoxytrityl- $N^{2}$-isobutyryl-2'-deoxyguanosine-3'-(2-cyanoethyl$N, N$-diisopropyl)phosphoramidite $\left(\mathrm{dG}^{i-\mathrm{Bu}}\right)$

$5^{\prime}$-O-Dimethoxytrityl- $N^{4}$-benzoyl-2'-deoxycytidine-3'-(2-cyanoethyl- $N, N$ diisopropyl)phosphoramidite $\left(\mathrm{dC}^{\mathrm{Bz}}\right)$

$5^{\prime}$-O-Dimethoxytrityl-2'-deoxythymidine-3'-(2-cyanoethyl- $N, N$ diisopropyl)phosphoramidite (T)

3:1 (v/v) concentrated $\mathrm{NH}_{4} \mathrm{OH} /$ ethanol

$1 \mathrm{M} n$-tetrabutylammonium fluoride (TBAF)/tetrahydrofuran (THF; Aldrich)

$10 \mathrm{mM} n$-tetrabutylammonium phosphate (TBAP), $\mathrm{pH} 7.5$, in $\mathrm{H}_{2} \mathrm{O}$

Automated DNA synthesizer (ABI Biotechnologies model 391 or 392) with 5' or 3' solid supports:

$5^{\prime}$ - $O$-Dimethoxytrityl- $N^{6}$-benzoyl-2'-deoxyadenosine-3'-lcaa-CPG $(1 \mu \mathrm{mol}$; $\mathrm{dA}^{\mathrm{Bz}}$-lcaa-CPG; ABI)

5'-O-Dimethoxytrityl- $N^{4}$-benzoyl-2'-deoxycytidine-3'-lcaa-CPG $(1 \mu \mathrm{mol}$; $\mathrm{dC}^{\mathrm{Bz}}$-lcaa-CPG; $\left.\mathrm{ABI}\right)$

5 - $O$-Dimethoxytrityl- $N^{2}$-isobutyryl-2'-deoxyguanosine-3'-lcaa-CPG (1 $\mu \mathrm{mol}$; $\mathrm{dG}^{i-\mathrm{Bu}}$-lcaa-CPG; ABI)

Synthesis and Characterization of Chimeric 2-5A-DNA Oligonucleotides $5^{\prime}$ - $O$-Dimethoxytritylthymidine-3'-lcaa-CPG ( $1 \mu \mathrm{mol}$; T-lcaa-CPG; ABI)

$3^{\prime}$-O $O$-Dimethoxytrityl- $N^{6}$-benzoyl-2'-deoxyadenosine-5'-lcaa-CPG $(1 \mu \mathrm{mol}$; Glen Research) 
3'-O-Dimethoxytrityl- $N^{4}$-benzoyl-2'-deoxycytidine-5'-lcaa-CPG (1 $\mu \mathrm{mol}$; Glen Research)

3'-O-Dimethoxytritylthymidine-5'-lcaa-CPG (1 $\mu \mathrm{mol}$; Glen Research)

3'-O-Dimethoxytrityl- $N^{2}$-isobutyryl-2'-deoxyguanosine-5'-lcaa-CPG (1 $\mu \mathrm{mol}$;

Glen Research).

Water bath at $55^{\circ} \mathrm{C}$

Speedvac evaporator

NOTE: The above-mentioned $5^{\prime}$ solid supports are used in the steps below. The $3^{\prime}$ solid supports are used in place of the $5^{\prime}$ supports when synthesizing oligonucleotides with terminal $\left(3^{\prime}-3^{\prime}\right)$-phosphodiester bonds.

\section{Synthesize 2-5A-antisense chimera}

For ABI 391 DNA synthesizer:

1a. Perform automated synthesis of 2-5A-antisense oligonucleotide on an ABI 391 DNA synthesizer according to manufacturer's instructions. Use manufacturer's $1 \mu \mathrm{mol}$ scale synthetic cycles for the antisense region and modify step 13 of the manufacturer's protocol for the remaining regions (see Table 4.4.1).

2a. Synthesize remaining regions of the chimera by sequentially adding $0.1 \mathrm{M}$ solutions of linker CE phosphoramidite, RNA CE phosphoramidite (2-5A), and phosphorylation reagent. Use monomer $\mathrm{CE}$ phosphoramidites that are $<1$ week old. To change reagents, sequentially place on bottle position no. 5 as follows:

a. Remove the previous reagent and replace with $5 \mathrm{~mL} \mathrm{CH}_{3} \mathrm{CN}$.

b. Remove the column feed line and dry the column by turning valve no. $14 \mathrm{ON}$ for $3 \mathrm{~min}$ and then $\mathrm{OFF}$, then turning function no. $105 \mathrm{ON}\left(4 \mathrm{~mL} \mathrm{CH}_{3} \mathrm{CN}\right.$ to column with the feed line unhooked) and then OFF. Replace column feed line.

c. Change bottle no. 5 to the next region's CE phosphoramidite.

d. Repeat for synthesis of each chimera domain.

For ABI 392 DNA synthesizer:

1b. Perform automated synthesis of 2-5A-antisense oligonucleotide on an ABI 392 DNA synthesizer according to manufacturer's instructions.

2b. Synthesize remaining regions of the chimera by adding linker $\mathrm{CE}$ phosphoramidite, RNA CE phosphoramidite (2-5A), and phosphorylation reagent using monomer

Table 4.4.1 Synthesis Conditions for Different Domains of the 2-5A-Antisense Chimera

\begin{tabular}{|c|c|c|c|c|}
\hline Chimera region & $\begin{array}{l}\text { Sequence no. and } \\
\text { monomer sequence }\end{array}$ & $\begin{array}{l}\text { Cycle no. and } \\
\text { coupling time }\end{array}$ & $\begin{array}{l}\text { Monomer CE } \\
\text { phosphoramidite }\end{array}$ & $\begin{array}{l}\text { Trityl } \\
\text { mode }\end{array}$ \\
\hline DNA antisense & $\begin{array}{l}\text { Sequence } 2 \\
5^{\prime}-\left(\mathrm{N}_{x}\right)-3^{\prime}\end{array}$ & $\begin{array}{l}\text { Cycle } 2 \\
15 \mathrm{sec}\end{array}$ & $\begin{array}{l}0.1 \text { M DNA CE } \\
\text { phosphoramidite }\end{array}$ & $\mathrm{ON}$ \\
\hline Linker & $\begin{array}{l}\text { Sequence } 4 \\
5^{\prime}-(\mathrm{LL})\left(\mathrm{N}_{x}\right)-3^{\prime}\end{array}$ & $\begin{array}{l}\text { Cycle } 4 \\
300 \mathrm{sec}\end{array}$ & $\begin{array}{l}0.1 \mathrm{M} \text { linker CE } \\
\text { phosphoramidite }\end{array}$ & $\mathrm{ON}$ \\
\hline $2-5 \mathrm{~A}$ & $\begin{array}{l}\text { Sequence } 3 \\
5^{\prime}-(\text { AAAA })\left(\operatorname{LLN}_{x}\right)-3^{\prime}\end{array}$ & $\begin{array}{l}\text { Cycle } 3 \\
600 \mathrm{sec}\end{array}$ & $\begin{array}{l}0.1 \mathrm{M} 2^{\prime}, 5^{\prime}-\mathrm{A}^{\mathrm{Bz} \text { or PAC }} \\
\text { RNA CE phosphoramidite }\end{array}$ & $\mathrm{ON}$ \\
\hline Phosphate & $\begin{array}{l}\text { Sequence } 1 \\
5^{\prime}-(\text { p)(AAAALLN } x)\end{array}$ & $\begin{array}{l}\text { Cycle } 1 \\
60 \mathrm{sec}\end{array}$ & $\begin{array}{l}0.2 \mathrm{M} \text { phosphorylation } \\
\text { reagent }\end{array}$ & OFF \\
\hline
\end{tabular}


positions 5,6 , and 7, respectively. Use monomer CE phosphoramidites that are $<1$ week old.

On the ABI 392, multiple cycle chimera sequences are created and saved on the computer's hard disk. The linker CE phosphoramidite, 2-5A CE phosphoramidite, and phosphorylation reagent are kept on monomer positions 5, 6, and 7, and need not be removed until they expire. This minimizes exposure to air. Average stepwise yield (ASWY) and overall yield are available for each synthesis.

Several cycles were created with the appropriate wait times by modification of the standard 1 umol CE cycle (1mmol linker, $1 \mathrm{mmol}$ phosphorylation). These changes are summarized in Table 4.4.2.

\section{Cleave 2-5A-antisense oligonucleotide from CPG and deprotect it}

3. Add $3 \mathrm{~mL}$ of $3: 1(\mathrm{v} / \mathrm{v})$ concentrated $\mathrm{NH}_{4} \mathrm{OH} /$ ethanol to the $\mathrm{CPG}$ support and incubate $2 \mathrm{hr}$ at room temperature.

4. Transfer to $55^{\circ} \mathrm{C}$ and incubate 8 to $12 \mathrm{hr}$.

Alternatively, in the case of all phenoxyacetyl (PAC)-protected bases, incubate at room temperature for $1 \mathrm{hr}$, followed by $55^{\circ} \mathrm{C}$ for $1 \mathrm{hr}$.

5. Transfer solution to a test tube, cool to $0^{\circ} \mathrm{C}$, and evaporate solvent in a Speedvac evaporator.

6. Remove 3'-O-TBDMS group from the 2-5A region of the chimera by adding $1 \mathrm{~mL}$ of $1 \mathrm{M} \mathrm{TBAF} / \mathrm{THF}$ and incubating 12 to $18 \mathrm{hr}$ at room temperature.

The chimera will normally remain in solution at the end of the incubation, and the solution will be homogenous. If it is not, briefly sonicate to achieve solution and incubate for another $4 \mathrm{hr}$.

7. Add $2 \mathrm{~mL}$ of $10 \mathrm{mM}$ TBAP, $\mathrm{pH} 7.5$, and remove THF in the Speedvac evaporator.

8. Dissolve crude chimera in distilled, deionized water to a total volume of $6 \mathrm{~mL}$, and purify by HPLC (see Basic Protocol 2).

If purification cannot be performed immediately, the chimera can be stored at $-70^{\circ} \mathrm{C}$ in the dry state for up to 2 weeks.

Synthesis and Characterization of Chimeric 2-5A-DNA Oligonucleotides

Table 4.4.2 Automated Synthesizer Coupling Times and Conditions

\begin{tabular}{|c|c|c|c|c|}
\hline $\begin{array}{l}\text { Chimera } \\
\text { region }\end{array}$ & Monomer sequence & $\begin{array}{l}\text { Cycle name and } \\
\text { coupling time }\end{array}$ & $\begin{array}{l}\text { Monomer CE } \\
\text { phosphoramidite }\end{array}$ & $\begin{array}{l}\text { Trityl } \\
\text { mode }\end{array}$ \\
\hline $\begin{array}{l}\text { DNA } \\
\text { antisense }\end{array}$ & $5^{\prime}-\left(\mathrm{N}_{x}\right)-3^{\prime}$ & $1 \mu \mathrm{mol} \mathrm{CE} ; 15 \mathrm{sec}$ & $\begin{array}{l}0.1 \text { M DNA CE } \\
\text { phosphoramidite }\end{array}$ & - \\
\hline Linker & $5^{\prime}-(\mathrm{LL})\left(\mathrm{N}_{x}\right)-3^{\prime}$ & $1 \mu \mathrm{mol}$ linker; $300 \mathrm{sec}$ & $\begin{array}{l}0.1 \mathrm{M} \text { linker CE } \\
\text { phosphoramidite }\end{array}$ & - \\
\hline $2-5 \mathrm{~A}$ & $5^{\prime}-(\mathrm{AAAA})\left(\mathrm{LLN}_{x}\right)-3^{\prime}$ & $1 \mu \mathrm{mol} \mathrm{RNA} ; 600 \mathrm{sec}$ & $\begin{array}{l}0.1 \mathrm{M} 2^{\prime}, 5^{\prime}-\mathrm{A}^{\mathrm{Bz}} \mathrm{RNA} \\
\text { CE phosphoramidite }\end{array}$ & - \\
\hline Phosphate & $5^{\prime}-(\mathrm{P})\left(\mathrm{AAAALLN}_{x}\right)-3^{\prime}$ & $\begin{array}{l}1 \mu \mathrm{mol} \text { phosphorylation; } \\
60 \mathrm{sec}\end{array}$ & $\begin{array}{l}0.2 \mathrm{M} \\
\text { phosphorylation } \\
\text { reagent }\end{array}$ & OFF \\
\hline Sulfurization & Any linkage & $\begin{array}{l}1 \mu \mathrm{mol} \text { phosphothioate; } \\
25 \mathrm{sec}, 5 \mathrm{sec} \text { delivery }\end{array}$ & $\begin{array}{l}\text { TETD/ } \mathrm{CH}_{3} \mathrm{CN} \text { bottle } \\
\text { no. } 10\end{array}$ & - \\
\hline
\end{tabular}




\section{PREPARATION OF KEY INTERMEDIATE FOR SYNTHESIS OF THE $\left(2^{\prime}, 5^{\prime}\right)$-OLIGOADENYLATE (2-5A) DOMAIN}

This protocol describes the procedures used to generate the appropriately protected phosphoramidite, $5^{\prime}$-O-(4,4'-dimethoxytrityl)-3'-O-(tert-butyldimethylsilyl)- $N^{6}$-benzoyladenosine- $2^{\prime}$-( $N, N$-diisopropyl-2-cyanoethyl)phosphoramidite for adding adenosine through the formation of a $2^{\prime}-5^{\prime}$ linkage to preformed antisense and linker domains. This phosphoramidite derivative may also be used to prepare unligated $\left(2^{\prime}-5^{\prime}\right)$-oligoadenylates using solid-phase synthesis.

\section{Materials}

Pyridine (Aldrich) dried over molecular sieves

Adenosine (Aldrich) dried overnight in vacuo over $\mathrm{P}_{2} \mathrm{O}_{5}$ (Aldrich)

4-Dimethylaminopyridine (DMAP; Aldrich)

Triethylamine (Aldrich)

4,4'-Dimethoxytrityl chloride (DMTr.Cl; Aldrich)

Chloroform $\left(\mathrm{CHCl}_{3}\right.$; Aldrich)

Methanol (Aldrich)

Trimethylsilyl chloride (Aldrich)

Benzoyl chloride (Aldrich)

Concentrated ammonium hydroxide (Aldrich)

Diethyl ether (Aldrich)

$\mathrm{MgSO}_{4}$ (anhydrous; Aldrich)

Kieselgel 60 silica gel (220 to 440 mesh; Fluka)

Ethyl acetate (Aldrich)

Toluene (Aldrich)

Imidazole (Aldrich)

tert-Butyldimethylsilyl chloride (TBDMS.Cl; Aldrich)

$\mathrm{N}, \mathrm{N}$-Dimethylformamide (DMF; anhydrous; Aldrich)

Cyclohexane (Aldrich)

$5 \%$ (w/v) aqueous $\mathrm{Na}_{2} \mathrm{CO}_{3}$

Methylene chloride $\left(\mathrm{CH}_{2} \mathrm{Cl}_{2} ;\right.$ Aldrich)

$1 H$-Tetrazole (Aldrich)

$\mathrm{P}_{2} \mathrm{O}_{5}$ (Aldrich)

Dry nitrogen

2-Cyanoethyl-( $N, N, N^{\prime} N^{\prime}$-tetraisopropyl)phosphoramidite (Aldrich)

Benzene

250-mL flask with ground-glass stopper

Rotary evaporator with vacuum pump

$2 \times 15$-cm, $5 \times 15-\mathrm{cm}$, and $5 \times 20$-cm chromatography columns

$25-\mathrm{mL}$ two-arm reaction flask fitted with a rubber septum

5-mL hypodermic syringe

Additional reagents and equipment for thin-layer chromatography (TLC) and fast silica gel column (flash) chromatography

\section{Synthesize $N^{6}$-benzoyl-5'-O-DMTr-adenosine}

1. Mix the following in a $250-\mathrm{mL}$ flask that can be sealed to the atmosphere:

$100 \mathrm{~mL}$ dry pyridine

$2.67 \mathrm{~g}(10 \mathrm{mmol})$ dry adenosine
Synthesis of 
$61 \mathrm{mg}(0.5 \mathrm{mmol})$ DMAP

$1.9 \mathrm{~mL}(14 \mathrm{mmol})$ triethylamine

$4.1 \mathrm{~g}$ (10 mmol) DMTr $\cdot \mathrm{Cl}$.

Introduce a magnetic stirring bar, seal the flask with a ground-glass stopper, and stir 2 to $3 \mathrm{hr}$ at room temperature.

2. Monitor the completeness of the reaction by analyzing an aliquot by silica gel TLC using 95:5 (v/v) $\mathrm{CHCl}_{3} / \mathrm{CH}_{3} \mathrm{OH}$ as the eluent. For comparison, run DMAP, adenosine, and DMTr$\cdot \mathrm{Cl}$ as TLC standards. Use care to completely evaporate the pyridine from the TLC plate before development.

3. When the tritylation reaction is complete, place in an ice/water bath to maintain at $0^{\circ} \mathrm{C}$, and slowly add $7.7 \mathrm{~mL}(60 \mathrm{mmol})$ trimethylsilyl chloride. Incubate $15 \mathrm{~min}$.

4. Allow mixture to warm to room temperature, add $5.8 \mathrm{~mL}$ ( $50 \mathrm{mmol})$ benzoyl chloride, and stir $\sim 2 \mathrm{hr}$ at room temperature.

5. Cool mixture in the ice/water bath, add $20 \mathrm{~mL}$ cold water, and allow to stand for 5 $\min$.

6. Add $20 \mathrm{~mL}$ concentrated ammonium hydroxide (final $2 \mathrm{M} \mathrm{NH}_{4} \mathrm{OH}$ ), allow to warm to room temperature, and incubate $30 \mathrm{~min}$ at room temperature.

7. Concentrate to $\sim 20 \mathrm{~mL}$ in a rotary evaporator in vacuo using a vacuum pump.

8. Add $700 \mathrm{~mL}$ diethyl ether, wash three times with $100 \mathrm{~mL}$ water, and dry the ether layer over $50 \mathrm{~g}$ anhydrous $\mathrm{MgSO}_{4}$.

9. Filter off $\mathrm{MgSO}_{4}$ and evaporate filtrate in a rotary evaporator.

10. Purify product by fast silica gel column (flash) chromatography using a $5 \times 20-\mathrm{cm}$ Kieselgel 60 (220 to 440 mesh) column and $2 \%$ methanol/0.2\% pyridine/ethyl acetate as an eluent. Collect 5-mL fractions.

11. Analyze fractions by TLC as above, combine fractions that contain product $\left(R_{\mathrm{f}}=0.6\right)$, and remove solvent in a rotary evaporator.

12. Remove last traces of residual pyridine by several additions and evaporations of toluene in 50-mL portions. Store, if necessary, dry at $4^{\circ} \mathrm{C}$ with a desiccant (stable at least 3 months).

This is a critical step to obtain a solid product.

The product should be obtained as a pale yellow solid foam (yield 50\% to 70\%): TLC $R_{f}$ $=0.55$ on silica gel (95:5 ethyl acetate/methanol); ${ }^{1} \mathrm{H} \mathrm{NMR:}\left(\mathrm{CDCl}_{3}\right) \delta[\mathrm{ppm}]: 3.34$ (dd, $1 \mathrm{H}, \mathrm{H}-5^{\prime}$ or $\left.5^{\prime \prime}\right), 3.49\left(\mathrm{dd},{ }^{1} \mathrm{H}, \mathrm{H}-5^{\prime}\right.$ or $\left.5^{\prime \prime}\right), 4.39\left(\mathrm{~d}, 1 \mathrm{H}, \mathrm{H}-4^{\prime}\right), 4.50\left(\mathrm{dd}, 1 \mathrm{H}, \mathrm{H}-3^{\prime}\right), 4.90(t$, $\left.1 \mathrm{H}, \mathrm{H}-2^{\prime}\right), 6.13\left(\mathrm{~d}, 1 \mathrm{H}, \mathrm{H}-\mathrm{I}^{\prime}\right), 6.74-7.60$ (m, aromatic protons), 8.02 and $8.04(\mathrm{~s}, 1 \mathrm{H}, \mathrm{H}-2$ or $H-8$ ).

Synthesize $N^{6}$-benzoyl-5'-O-DMTr-2'-O-TBDMS-adenosine and $N^{6}$-benzoyl-5'-ODMTr-3'-O-TBDMS-adenosine

13. Dissolve the following and maintain at room temperature for $2.5 \mathrm{hr}$ :

Synthesis and Characterization of Chimeric 2-5A-DNA Oligonucleotides
$1.75 \mathrm{~g}(2.6 \mathrm{mmol}) N^{6}$-benzoyl-5'-O-DMTr-adenosine

$0.544 \mathrm{~g}(8 \mathrm{mmol})$ imidazole

$0.60 \mathrm{~g}(5 \mathrm{mmol}) \mathrm{TBDMS} \cdot \mathrm{Cl}$

$10 \mathrm{~mL}$ anhydrous DMF. 
14. Verify that all $N^{6}$-benzoyl-5'-O-DMTr-adenosine has reacted by running an aliquot on a silica gel TLC plate using 95:5 (v/v) ethyl acetate/methanol or 1:1 (v/v) ethyl acetate/cyclohexane as the eluent.

15. Add $1.5 \mathrm{~mL}$ of $5 \%$ aqueous $\mathrm{Na}_{2} \mathrm{CO}_{3}$ at $0^{\circ} \mathrm{C}$ to stop the reaction. Stir $15 \mathrm{~min}$ at $<10^{\circ} \mathrm{C}$.

16. Evaporate DMF in a rotary evaporator in vacuo, dissolve the resulting residue in 50 $\mathrm{mL} \mathrm{CH} \mathrm{Cl}_{2}$, and wash three times with $50 \mathrm{~mL}$ water.

17. Dry $\mathrm{CH}_{2} \mathrm{Cl}_{2}$ layer over anhydrous $\mathrm{MgSO}_{4}$ and then evaporate solvent using a rotary evaporator.

18. Dissolve residue in $10 \mathrm{~mL}$ of $1: 1(\mathrm{v} / \mathrm{v})$ ethyl acetate/cyclohexane containing $0.2 \%$ pyridine and apply to a $5 \times 15-\mathrm{cm}$ Kieselgel 60 silica gel column. Elute with 49:49:2 (v/v/v) ethyl acetate/cyclohexane/pyridine. Collect 5-mL fractions.

19. Monitor elution of reaction products using silica gel TLC with 1:1:0.004 (v/v/v) ethyl acetate/cyclohexane/pyridine.

The first product to elute is the 2'-O-silylated isomer: $N^{6}$-benzoyl-5'-O-DMTr-2'-OTBDMS-adenosine $\left(R_{f}=0.47\right)$. After complete elution of the $2^{\prime}$-O-silylated isomer, the concentration of ethyl acetate must be increased to elute the 3 '-O-silylated isomer.

20. Switch eluent to ethyl acetate/cyclohexane/pyridine $66: 32: 2(\mathrm{v} / \mathrm{v} / \mathrm{v})$ and continue TLC monitoring for elution of the 3 '- $O$-silylated isomer.

$$
N^{6} \text {-Benzoyl-5'-O-DMTr-3'-O-TBDMS-adenosine has an } R_{f} \text { of } 0.24 \text {. }
$$

21. Pool appropriate fractions containing each of the respective products and remove the solvent by rotary evaporation in vacuo. Subsequently add and evaporate $50-\mathrm{mL}$ portions of toluene to remove traces of pyridine as judged by smell. Store, if necessary, dry at $4^{\circ} \mathrm{C}$ with a desiccant (stable at least 3 months).

The products are obtained as colorless foams (typical yields: $480 \mathrm{mg} 2$ '-O-silylated isomer; $660 \mathrm{mg}$ 3'-O-silylated isomer). By silica gel TLC using 1:1:0.004 ethyl acetate/cyclohexane/pyridine, the $2^{\prime}$-isomer has a $R_{f}=0.47$ and the $3^{\prime}$-isomer has a $R_{f}=0.24$. The product used for further synthesis of 2-5A and 2-5A-antisense oligonucleotide is the 3'-O-silylated isomer: $1 \mathrm{H} \mathrm{NMR:}\left(\mathrm{CDCl}_{3}\right), \delta(\mathrm{ppm}): 0.02$ and $0.10\left(\mathrm{ds}, 6 \mathrm{H}, \mathrm{CH}_{3} \mathrm{Si}\right), 0.98(\mathrm{~s}, 9 \mathrm{H}, \mathrm{t}$-butyl), 3.27 and $3.54\left(\mathrm{dd}, 1 \mathrm{H}, \mathrm{H}-5^{\prime}\right.$ or $\left.\mathrm{H}-5^{\prime \prime}\right), 3.77\left(\mathrm{~s}, 3 \mathrm{H}, \mathrm{CH}_{3} \mathrm{O}\right), 4.21\left(\mathrm{~m}, 1 \mathrm{H}, \mathrm{H}-4^{\prime}\right), 4.60(\mathrm{t}, 1 \mathrm{H}$, $\left.H-3^{\prime}\right), 4.80\left(t, 1 H, H-2^{\prime}\right), 6.10\left(\mathrm{~d}, 1 \mathrm{H}, \mathrm{H}-\mathrm{l}^{\prime}\right), 8.03$ and 8.05 (s, $1 \mathrm{H}, \mathrm{H}-2$ or $\left.\mathrm{H}-8\right), 6.78-7.60$, $8.28,8.77$ (m, aromatic protons).

It is critical that complete separation of the silylated isomers be accomplished at this stage. Separation will be impossible after generation of the phosphoramidite. This is the most common cause of difficulty in this procedure.

\section{Synthesize $N^{6}$-benzoyl-5'-O-DMTr-3'-O-TBDMS-adenosine-2'-(N,N-diisopropyl-2- cyanoethyl)phosphoramidite}

22. Combine $48 \mathrm{mg}(0.68 \mathrm{mmol})$ of $1 H$-tetrazole and $540 \mathrm{mg}(0.68 \mathrm{mmol})$ of $N^{6}$-benzoyl-5'-O-DMTr-3'-O-TBDMS-adenosine in a $25-\mathrm{mL}$ two-arm reaction flask fitted with a rubber septum and a hypodermic needle.

For this reaction, additional care must be taken to ensure anhydrous reaction conditions. The hypodermic needle is used for evacuation of air and admission of dry nitrogen and reagents.

23. Place the flask, fittings, and contents in a vacuum desiccator and dry overnight in vacuo in the presence of $\mathrm{P}_{2} \mathrm{O}_{5}$.

24. Admit dry nitrogen to the desiccator and thus to the reaction flask. Immediately remove the hypodermic needle from the rubber septum. 
SUPPORT PROTOCOL 2

Synthesis and Characterization of Chimeric 2-5A-DNA Oligonucleotides
25. Add a solution of $5 \mathrm{~mL} \mathrm{CH} \mathrm{Cl}_{2}$ and $206 \mathrm{mg}$ ( $\left.0.68 \mathrm{mmol}\right)$ of 2-cyanoethyl-( $N, N, N^{\prime}, N^{\prime}$ tetraisopropyl)phosphoramidite through the rubber septum using a 5 -mL hypodermic syringe and needle.

26. Incubate $4 \mathrm{hr}$ at room temperature and then overnight at $4^{\circ} \mathrm{C}$.

27. Evaporate reaction mixture in vacuo on a rotary evaporator.

28. Add $2 \mathrm{~mL}$ of $6: 3: 1(\mathrm{v} / \mathrm{v} / \mathrm{v})$ benzene/cyclohexane/triethylamine to the residue and apply to a $2 \times 15-\mathrm{cm}$ silica gel (Kieselgel 60) column. Use the same solvent for product elution. Collect 5-mL fractions.

29. Monitor fractions by silica gel TLC using 6:3:1 (v/v/v) benzene/cyclohexane/triethylamine as eluent.

Two major products are generated in this reaction, namely, the two $P$-chiral diastereomers. These two stereoisomers have $R_{f}$ values of 0.61 and 0.53 by silica gel TLC with this solvent.

30. Combine product-containing fractions, concentrate to dryness in vacuo, and dry by addition and evaporation of $50-\mathrm{mL}$ portions of toluene.

The product can be stored at $4^{\circ} \mathrm{C}$.

A partial separation of these two diastereomers can be achieved, but in practice this is not necessary. The product, consisting of a mixture of both P-chiral diastereoisomers, is obtained as a colorless foam ( $500 \mathrm{mg}) ;{ }^{31} \mathrm{P} \mathrm{NMR:}\left(\mathrm{CDCl}_{3}, 1 \% \mathrm{C}_{5} \mathrm{D}_{5} \mathrm{~N}\right): \delta(\mathrm{ppm}) 150.73$ and 150.38 .

\section{PREPARATION OF A LINKER INTERMEDIATE THAT JOINS $\left(2^{\prime}-5^{\prime}\right)$-OLIGOADENYLATE (2-5A) TO ANTISENSE $\left(3^{\prime}-5^{\prime}\right)$-OLIGODEOXYRIBONUCLEOTIDES}

This protocol describes the synthesis of 4-O-(4,4'-dimethoxytrityl)oxybutyl-1-[(2-cyanoethyl)- $N, N$-diisopropylphosphoramidite], which is the moiety used in the prototype 2-5A-antisense chimera to join the 2-5A domain to the antisense domain.

\section{Materials}

1,4-Butanediol (Aldrich)

Pyridine (anhydrous; Aldrich)

Dry argon or nitrogen (Aldrich)

4,4'-Dimethoxytrityl chloride (DMTr.Cl; Aldrich)

Chloroform (Aldrich)

Methanol (Aldrich)

Ethyl acetate (Aldrich)

$\mathrm{MgSO}_{4}$ (anhydrous; Aldrich)

Kieselgel 60 silica gel (Fluka)

Methylene chloride $\left(\mathrm{CH}_{2} \mathrm{Cl}_{2}\right.$; Aldrich)

Ethyldiisopropylamine (Aldrich)

2-Cyanoethyl- $N, N$-diisopropylphosphoramidic chloride (Aldrich)

Benzene (Aldrich)

Petroleum ether (Aldrich)

Triethylamine (Aldrich)

250-ml stoppered flask

Rotary evaporator attached to a vacuum pump

Hand-held UV lamp 
Additional reagents and equipment for thin-layer chromatography (TLC) and fast silica gel column (flash) chromatography

\section{Synthesize 4-O-(4,4'-dimethoxytrityl)oxybutan-1-ol}

1. Dissolve $9.0 \mathrm{~g}(100 \mathrm{mmol})$ of 1,4 -butanediol in $50 \mathrm{~mL}$ anhydrous pyridine in a $250-\mathrm{ml}$ stoppered flask.

2. Remove pyridine by evaporation at $<40^{\circ} \mathrm{C}$ in a rotary evaporator attached to a vacuum pump.

3. Through the rotary evaporator stopcock, admit dry argon or nitrogen to the flask containing the butanediol, add an additional $50 \mathrm{~mL}$ dry pyridine, and repeat the evaporation procedure.

4. Repeat step 3 once more. Be certain to admit the dry nitrogen or argon after the final pyridine evaporation.

A total of three evaporations will dry the butanediol sufficiently for the following tritylation reaction.

5. Dissolve dried 1,4-butanediol in $50 \mathrm{~mL}$ anhydrous pyridine.

6. Add $3.39 \mathrm{~g}(10 \mathrm{mmol}) \mathrm{DMTr} \cdot \mathrm{Cl}$ and allow the homogenous mixture to react $2 \mathrm{hr}$ at room temperature in the stoppered flask.

7. Verify complete formation of the product by TLC using 99:1 (v/v) chloroform/methanol as developing solvent.

8. Pour the entire mixture onto $100 \mathrm{~g}$ ice in a beaker. Add a magnetic stirring bar and stir the mixure until the ice is completely melted.

9. Add $100 \mathrm{~mL}$ ethyl acetate and shake to extract the organic product. Separate the organic (top) and aqueous (bottom) layers.

10. Reextract the aqueous layer with an additional $50 \mathrm{~mL}$ ethyl acetate. Separate the organic layer again, and add the ethyl acetate layer to the one obtained from the previous extraction.

11. Add $10 \mathrm{~g}$ anhydrous $\mathrm{MgSO}_{4}$ to the combined organic layers to dry them. Filter off $\mathrm{MgSO}_{4}$ and evaporate all but $\sim 10 \mathrm{~mL}$ ethyl acetate solution in a rotary evaporator at $<40^{\circ} \mathrm{C}$.

12. Add the concentrated ethyl acetate solution to the top of a column containing $250 \mathrm{~g}$ silica gel (Kieselgel 60). Elute with 99:1 (v/v) methylene chloride/methanol, collecting $10-\mathrm{mL}$ fractions.

13. Check each fraction for product by spotting aliquots on a silica gel TLC plate and looking for the presence of UV-absorbing material with a hand-held UV lamp. If UV absorbance is detected, develop the plate using 99:1 (v/v) chloroform/methanol.

Approximately $2.1 \mathrm{~g}$ (54\% overall yield) of 4-O-(4,4'-dimethoxytrityl)oxybutan-1-ol can be obtained: ${ }^{1} \mathrm{H} \mathrm{NMR}\left(\mathrm{CDCl}_{3}, 1 \%\right.$ deuteriopyridine $): \delta(\mathrm{ppm}) 1.68\left(\mathrm{~m}, 4 \mathrm{H}, \mathrm{CH}_{2}\right) ; 3.10(\mathrm{t}, \mathrm{J}$ $\left.=5.7 \mathrm{~Hz}, 2 \mathrm{H}, \mathrm{CH}_{2} \mathrm{O}\right) ; 3.62\left(\mathrm{t}, \mathrm{J}=5.8 \mathrm{~Hz}, 2 \mathrm{H}, \mathrm{CH}_{2} \mathrm{OH}\right) ; 3.76\left(\mathrm{~s}, 6 \mathrm{H}, \mathrm{CH}_{3} \mathrm{O}\right) ; 6.79-7.46$ ( $m$, aromatic protons).

Synthesize 4-O-(4,4'-dimethoxytrityl)oxybutyl-1-[(2-cyanoethyl)-N,N-diisopropylphosphoramidite]

14. Prepare a solution of the following reagents under anhydrous conditions:

$390 \mathrm{mg}$ (1 mmol) 4-O-(4,4'-dimethoxytrityl)oxybutan-1-ol 
$3 \mathrm{~mL}$ dry methylene chloride.

Cool in an ice bath.

15. Slowly add $237 \mathrm{mg}$ (1 mmol) of 2-cyanoethyl- $N, N$-diisopropylphosphoramidic chloride under anhydrous conditions. Allow to warm to room temperature and to react for $1 \mathrm{hr}$.

16. Evaporate solvent using a rotary evaporator at $<40^{\circ} \mathrm{C}$.

17. Dissolve residue in $5 \mathrm{~mL}$ benzene and add mixture to the top of a $1.8 \times 14-\mathrm{cm}$ silica gel column. Elute the product with 6:3:1 (v/v/v) benzene/petroleum ether/triethylamine.

18. Check fractions for product by silica gel TLC using 6:3:1 (v/v/v) benzene/petroleum ether/triethylamine as the eluent.

19. Evaporate solvent from product-containing fractions.

Yield: $580 \mathrm{mg}$ (98\%) 4-O-(4,4'-dimethoxytrityl)oxybutyl-1-[(2-cyanoethyl)-N,N-diisopropylphosphoramidite $]:{ }^{1} \mathrm{H} N \mathrm{NR}\left(\mathrm{CDCl}_{3}, 1 \%\right.$ deuteriopyridine $): \delta(\mathrm{ppm}) 1.17(t, \mathrm{~J}=7.0$ $\left.\mathrm{Hz}, 12 \mathrm{H}, \mathrm{CH}_{3} \mathrm{C}\right) ; 1.70\left(\mathrm{~m}, 4 \mathrm{H}, \mathrm{CH}_{2} \mathrm{C}\right) ; 2.60\left(t, \mathrm{~J}=6.5 \mathrm{~Hz}, 2 \mathrm{H}, \mathrm{CH}_{2} \mathrm{CN}\right), 3.08(t, \mathrm{~J}=5.7$ $\left.\mathrm{Hz}, 2 \mathrm{H}, \mathrm{CH}_{2} \mathrm{O}\right) ; 3.80(\mathrm{~m}, 2 \mathrm{H}, \mathrm{CH}) ; 6.80-7.49$ (m, aromatic protons); ${ }^{31} \mathrm{P} \mathrm{NMR}\left(\mathrm{CDCl}_{3}\right.$, $1 \%$ deuteriopyridine): $\delta$ (

This phosphoramidite, like all phosphoramidites, is best stored in the presence of a desiccant at $-20^{\circ} \mathrm{C}$.

BASIC

PROTOCOL 2

Synthesis and Characterization of Chimeric 2-5A-DNA Oligonucleotides

\section{PURIFICATION AND CHROMATOGRAPHIC CHARACTERIZATION OF CHIMERIC 2-5A ANTISENSE OLIGONUCLEOTIDES}

After deprotection, the chimera can be purified using either reversed-phase ion-pair chromatography or anion-exchange chromatography. The polystyrene reversed-phase ion-pair (PRP-1) column has a long lifetime, can tolerate extremes of $\mathrm{pH}$ and fluoride ions, and gives good recoveries of the 2-5A-antisense chimera. Desalting prior to ion-pair HPLC is not required, but is performed after. A typical chromatogram of a representative crude chimera is shown in Figure 4.4.2. The Nucleogen DEAE anion-exchange column has a shorter lifetime than the PRP-1 column, and cannot tolerate extremes of $\mathrm{pH}$ and fluoride ions. Preparative purification requires prior desalting. In addition, recoveries of chimera are poorer than those accomplished with the PRP-1 procedure. After purification by ion-pair or anion-exchange chromatography, the chimera is converted to a sodium salt by cation exchange, dialyzed, and filter sterilized. The purity of the chimera is estimated by capillary gel electrophoresis and ion-exchange HPLC.

\section{Materials}

Crude 2-5A-antisense chimera (see Basic Protocol 1)

Solvent A: $10 \mathrm{mM} n$-tetrabutylammonium phosphate (TBAP), $\mathrm{pH} 7.5$, in $\mathrm{H}_{2} \mathrm{O}$ (for ion-pair chromatography)

Solvent B: $10 \mathrm{mM}$ TBAP, $\mathrm{pH} 7.5$, in 8:2 (v/v) $\mathrm{CH}_{3} \mathrm{CN} / \mathrm{H}_{2} \mathrm{O}$ (for ion-pair chromatography)

Methanol

Solvent C: $20 \mathrm{mM}$ potassium phosphate, $\mathrm{pH} 7.0$, in 8:2 (v/v) $\mathrm{CH}_{3} \mathrm{CN} / \mathrm{H}_{2} \mathrm{O}$ (for anion-exchange chromatography)

Solvent D: $20 \mathrm{mM}$ potassium phosphate, $\mathrm{pH} 7.0$, in aqueous $1 \mathrm{M} \mathrm{KCl}$ (for anion-exchange chromatography)

Dowex 50W ( $\mathrm{Na}^{+}$form; Bio-Rad)

Tris/methanol running buffer: $75 \mathrm{mM}$ Tris phosphate, $\mathrm{pH} 7.6$, in 9:1 (v/v) $\mathrm{H}_{2} \mathrm{O}$ /methanol 


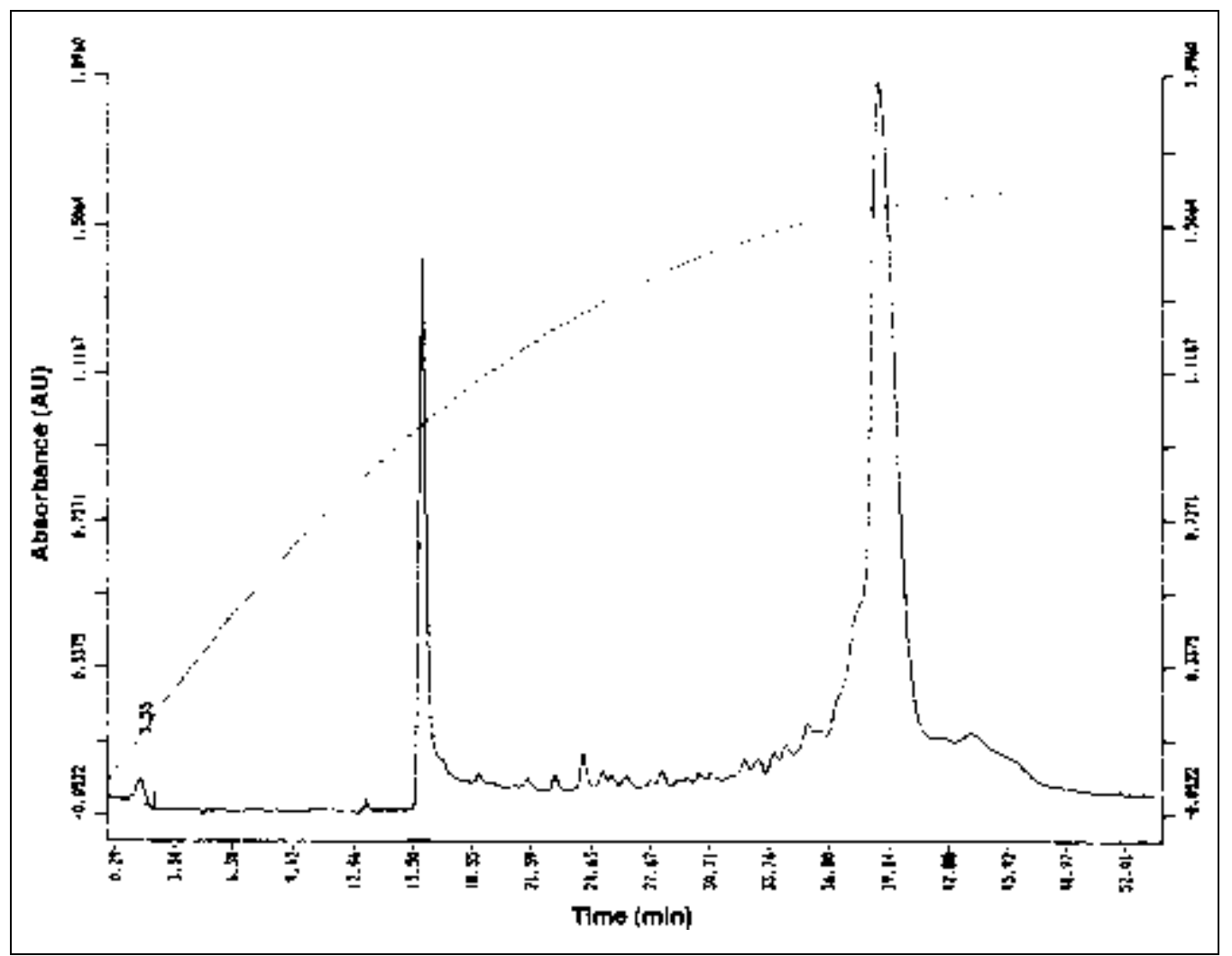

Figure 4.4.2 Polystyrene reversed-phase ion-pair chromatography of the crude (post-deprotection) 2-5A-DNA chimera: 5'-pA $\left(2^{\prime}, 5^{\prime}-\mathrm{pA}\right)_{3}-2^{\prime}-\mathrm{p}\left[\left(\mathrm{CH}_{2}\right)_{4} \mathrm{p}\right]_{2} \mathrm{~d}[\mathrm{TCT}$ CCG CTT CTT CCT GCC AT]. A 33 $\times 7-\mathrm{mm}$ PRP-1 column was used and elution was accomplished with a convex gradient of $5 \%$ to $80 \%$ solvent $B$ in solvent $A$ over $50 \mathrm{~min}$, where solvent $A$ was $10 \mathrm{mM} n$-tetrabutylammonium phosphate (TBAP), pH 7.5, and solvent B was $10 \mathrm{mM}$ TBAP in 8:2 (v/v) methanol/water, $\mathrm{pH} 7.5$. The flow rate was $1.5 \mathrm{~mL} / \mathrm{min}$. Detection was at $270 \mathrm{~mm}$. The major peak at a retention time of $\sim 39$ min was collected.

Solvent E: $25 \mathrm{mM}$ Tris.Cl, pH 7.0 (APPENDIX 2A) in 1:200 (v/v) $\mathrm{CH}_{3} \mathrm{CN} / \mathrm{H}_{2} \mathrm{O}$ Solvent F: $25 \mathrm{mM}$ Tris. $\mathrm{Cl}, 1 \mathrm{M}$ ammonium chloride, $\mathrm{pH}$ 7.0, in 1:200 (v/v) $\mathrm{CH}_{3} \mathrm{CN} / \mathrm{H}_{2} \mathrm{O}$

High-performance liquid chromatograph (HPLC) with 270-nm UV detection $300 \times 7$-mm polystyrene reversed-phase column (PRP-1 semi-prep column; 10 $\mu \mathrm{m}, 100 \AA$; Hamilton; for ion-pair chromatography)

Speedvac evaporator

SepPak C18 cartridge

$125 \times 4$-mm Nucleogen DEAE 60-7 column ( $7 \mu \mathrm{m}, 60 \AA$ A; Macherey-Nagel; for anion-exchange chromatography)

PolyPrep column

Millex-GV 0.22- $\mu \mathrm{m}$ filter unit (Millipore)

SpectraPor dialysis chamber $\left(V_{\mathrm{t}}=5 \mathrm{~mL}\right)$ with a $3500 \mathrm{MWCO}$ membrane (Spectrum)

Capillary electrophoresis instrument (ABI model 270A-HT) with MICRO-GEL 100 gel-filled capillaries (50- $\mu \mathrm{m}$ i.d., $27-\mathrm{cm}$ effective length) and UV detection at $260 \mathrm{~nm}$

$250 \times 4$-mm Dionex PA-100 column (Dionex)

Additional reagents and equipment for determining $\mathrm{OD}_{260}$ (UNIT 10.3)

Synthesis of Modified Oligonucleotides and Conjugates 


\section{Purify 2-5A-antisense chimera}

For reversed-phase ion-pair chromatography:

1a. Inject $1 \mathrm{~mL}$ crude $2-5 \mathrm{~A}$-antisense chimera into a $300 \times 7-\mathrm{mm}$ polystyrene reversedphase column.

2a. Elute purified chimera using a convex gradient from 5:95 (v/v) solvents B/A to 80:20 solvents B/A over $45 \mathrm{~min}$, at a flow rate of $1.5 \mathrm{~mL} / \mathrm{min}$. Collect $1-\mathrm{mL}$ fractions and use UV detection at $270 \mathrm{~nm}$.

3a. Combine fractions according to the UV profile, and evaporate to dryness in a Speedvac evaporator.

4a. Wash a SepPak C18 cartridge sequentially with $10 \mathrm{~mL}$ methanol and $10 \mathrm{~mL} \mathrm{H}_{2} \mathrm{O}$ to remove shipping buffer.

5a. Dissolve chimera in 2 to $4 \mathrm{~mL} \mathrm{H}_{2} \mathrm{O}$ and load onto the cartridge.

6a. Wash cartridge sequentially with $15 \mathrm{~mL} \mathrm{H} \mathrm{H}_{2} \mathrm{O}, 10 \mathrm{~mL}$ of 5:95 (v/v) methanol/ $\mathrm{H}_{2} \mathrm{O}$, and $10 \mathrm{~mL}$ of $1: 9(\mathrm{v} / \mathrm{v})$ methanol/ $\mathrm{H}_{2} \mathrm{O}$.

7a. Elute chimera with $10 \mathrm{~mL}$ of $1: 1(\mathrm{v} / \mathrm{v})$ methanol/ $\mathrm{H}_{2} \mathrm{O}$ and concentrate the eluate as needed in a Speedvac evaporator. Proceed to step 8.

For anion-exchange chromatography:

1b. Desalt crude 2-5A-antisense chimera as described in steps $4 \mathrm{a}$ to $7 \mathrm{a}$.

2b. Inject $1 \mathrm{~mL}$ chimera in water onto a $125 \times 4-\mathrm{mm}$ Nucleogen DEAE 60-7 column.

3b. Elute purified chimera using a linear gradient from 1:99 (v/v) solvents D/C to $100 \%$ solvent D over $30 \mathrm{~min}$, followed by isocratic elution for $15 \mathrm{~min}$, all at a flow rate of $1.0 \mathrm{~mL} / \mathrm{min}$. Collect 1-mL fractions and use UV detection at $260 \mathrm{~nm}$.

4b. Combine fractions as indicated by the UV profile, and evaporate to dryness in a Speedvac evaporator. Proceed to step 8.

\section{Convert chimera to its sodium salt by cation exchange}

8. Dissolve tetrabutylammonium salt (step 7a) or potassium salt (step $4 b$ ) of the chimera in $2 \mathrm{~mL}$ water.

9. Add $1 \mathrm{~mL}$ Dowex $50 \mathrm{~W}$ slurry $\left(\mathrm{Na}^{+}\right.$form) and stir $3 \mathrm{hr}$ at $4{ }^{\circ} \mathrm{C}$.

10. Remove resin by passing the suspension through an empty PolyPrep column.

11. Elute chimera from the resin with $17 \mathrm{~mL} \mathrm{H}_{2} \mathrm{O}$. Be sure to monitor the recovery by $\mathrm{UV}$, as the oligonucleotide is retarded by the Dowex.

\section{Dialyze and sterilize chimera}

12. Sterilize solution through a Millex-GV $0.22-\mu \mathrm{m}$ filter unit.

13. Dialyze against water overnight at $4^{\circ} \mathrm{C}$, using a SpectraPor dialysis chamber $\left(V_{\mathrm{t}}=5\right.$ $\mathrm{mL}$ ) with a $3500 \mathrm{MWCO}$ membrane.

14. Repeat step 12. Determine $\mathrm{OD}_{260}($ UNIT 10.3) to quantitate DNA. the chimera for biological evaluation. 


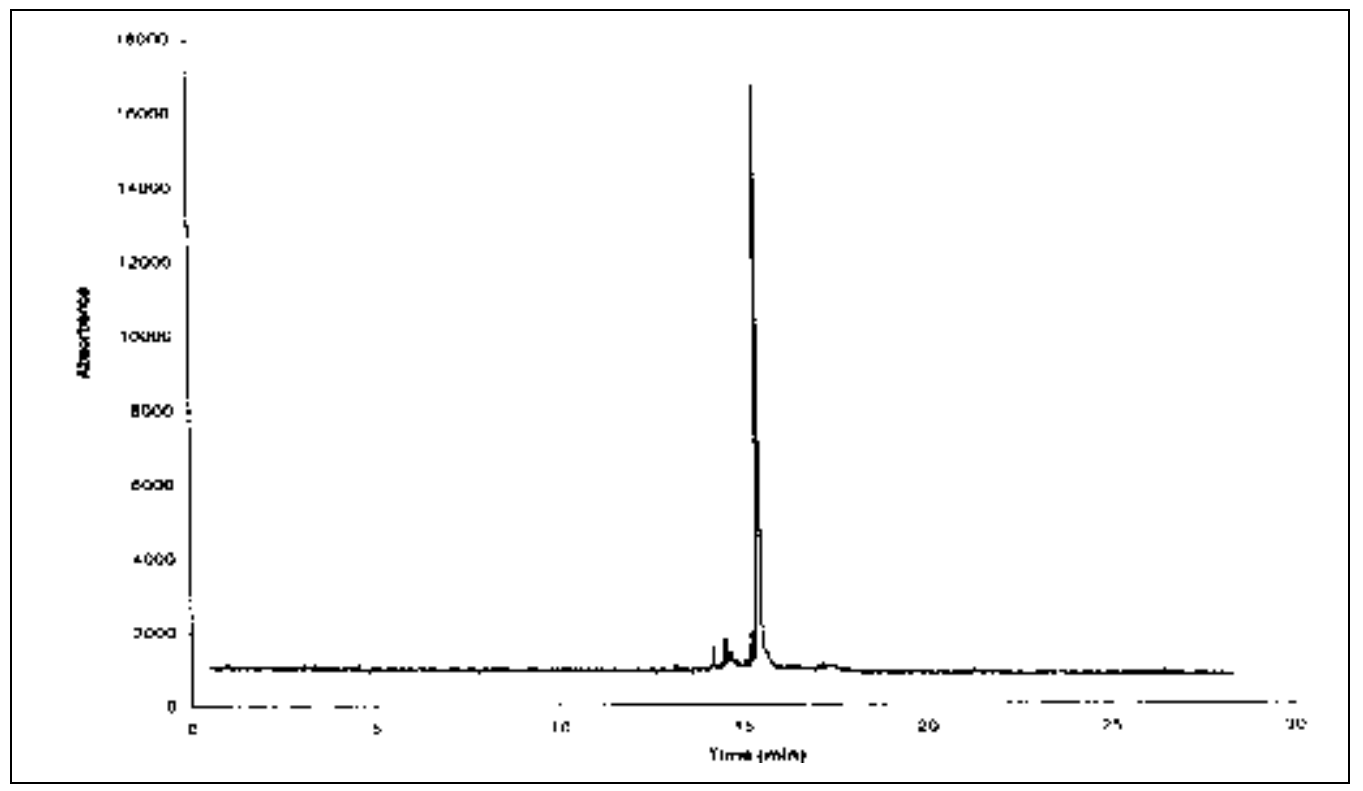

Figure 4.4.3 Determination of 2-5A-antisense chimera purity by capillary gel electrophoresis on an $\mathrm{ABI}$ 270A-HT instrument using MICRO-GEL 100 gel-filled capillaries (50- $\mu \mathrm{m}$ i.d., 27-cm effective length) with a running buffer of $75 \mathrm{mM}$ Tris phosphate, $\mathrm{pH} 7.6$, in 9:1 (v/v) $\mathrm{H}_{2} \mathrm{O} / \mathrm{methanol}$. The voltage was $-14 \mathrm{kV}$ and the operation $T$ was $30^{\circ} \mathrm{C}$. Detection was at $260 \mathrm{~nm}$. The typical chromatogram shown is for the chimera: $5^{\prime}-\mathrm{pA}\left(2^{\prime}, 5^{\prime}-\mathrm{pA}\right)_{3}-2^{\prime}-\mathrm{p}\left[\left(\mathrm{CH}_{2}\right)_{4} \mathrm{p}\right]_{2} \mathrm{~d}[\mathrm{TCT}$ CCG CTT CTT CCT GCC AT].

\section{Estimate chimera purity by capillary gel electrophoresis}

15. Determine oligonucleotide chimera purity on an ABI 270A-HT capillary electrophoresis instrument using MICRO-GEL ${ }_{100}$ gel-filled capillaries and Tris/methanol running buffer with UV detection at $260 \mathrm{~nm}$. Run at $-14 \mathrm{kV}(17 \mu \mathrm{A})$ and at an operation temperature of $30^{\circ} \mathrm{C}$.

Typically, a chimera electropherogram can be obtained using a sample concentration of $0.06 \mathrm{OD}_{260}$ and an electrokinetic injection of $2 \mathrm{~s}$ at $-5 \mathrm{kV}$. A typical electropherogram is shown in Figure 4.4.3.

\section{Estimate chimera purity by ion-exchange HPLC}

16. Carry out ion-exchange HPLC using a $250 \times 4-m m$ Dionex PA-100 column. Use an injection volume of $50 \mu \mathrm{L}$ and $\sim 0.1 \mathrm{OD}_{260}$ of oligonucleotide. Employ a linear gradient from 1:9 (v/v) solvents F/E to 9:1 solvents F/E over 25 min, followed by isocratic elution for $25 \mathrm{~min}$, all at a flow rate of $1.0 \mathrm{~mL} / \mathrm{min}$ with $\mathrm{UV}$ detection at $270 \mathrm{~nm}$.

The Dionex PA-100 column gives better peak shape than many other ion-exchange columns.

\section{COMPOSITION ANALYSIS OF CHIMERIC 2-5A-ANTISENSE OLIGONUCLEOTIDES USING SNAKE VENOM PHOSPHODIESTERASE DIGESTION AND REVERSED-PHASE HPLC}

When 2-5A-antisense chimeric oligonucleotides are digested by snake venom phosphodiesterase (SVPD), they yield 5'-AMP from the 2-5A domain, 5'-pA2'-p $\left(\mathrm{CH}_{2}\right)_{4} \mathrm{p}^{\prime}\left(\mathrm{CH}_{2}\right)_{4} \mathrm{OH}$ from the terminal AMP of 2-5A and the linker moiety, and deoxyribonucleotide $5^{\prime}$-monophosphates from the antisense domain. This analysis provides a cornucopia of valuable information regarding the 2-5A-antisense chimera. It provides a compositional analysis (by providing the ratio of $5^{\prime}$-AMP to any or all of the constituent $5^{\prime}$-deoxyribonucleotides) and 
also ascertains the completeness of 5'-phosphorylation (through the appearance of adenosine as a product of $5^{\prime}$-unphosphorylated chimera), which is vital for full activation of RNase L.

\section{Materials}

Purified 2-5A-antisense chimera (see Basic Protocol 2)

Snake venom phosphodiesterase (SVPD, Crotallus adamanteus; Amersham

Pharmacia Biotech)

$1 \mathrm{M}$ Tris.Cl, pH 8.0 (APPENDIX 2A)

$1 \mathrm{M} \mathrm{MgCl}_{2}$

Solvent A: aqueous $100 \mathrm{mM}$ ammonium phosphate, $\mathrm{pH} 5.5$

Solvent B: $1: 1(\mathrm{v} / \mathrm{v})$ methanol/ $\mathrm{H}_{2} \mathrm{O}$

Microcon-10 concentrator (Amicon)

High-performance liquid chromatograph (HPLC) with $250 \times 4.6-\mathrm{mm}$ Ultrasphere C18 ODS column $(5 \mu \mathrm{m}, 80 \AA$; Thomson Instrument)

1. Analyze the nucleotide composition of purified 2-5A-antisense chimera by digestion with SVPD. Mix the following and incubate $3 \mathrm{hr}$ at $37^{\circ} \mathrm{C}$ :

$0.2 \mathrm{OD}_{260}$ units chimera

0.15 units SVPD

$50 \mathrm{mM}$ Tris $\cdot \mathrm{Cl}, \mathrm{pH} 8.0$

$0.5 \mathrm{mM} \mathrm{MgCl}{ }_{2}$

water to $100 \mu \mathrm{L}$.

2. Wash the membrane of a Microcon-10 concentrator with $100 \mu \mathrm{L}$ water and then with $100 \mu \mathrm{L}$ solvent A to remove shipping buffer. Centrifuge each wash $5 \mathrm{~min}$ at $700 \times g, 4^{\circ} \mathrm{C}$ (see manufacturer's instructions).

Each spin-rinse takes $\sim 15$ min.

3. Discard filtrate, apply $100 \mu \mathrm{L}$ enzyme digestion mixture, and spin-rinse for $15 \mathrm{~min}$.

4. Wash membrane three more times with $100-\mu \mathrm{L}$ portions of solvent $\mathrm{A}$ to ensure that all nucleotides have passed through the membrane.

5. Analyze the centrifugate by reversed-phase HPLC using a $250 \times 4.6-\mathrm{mm}$ Ultrasphere C18 ODS column. Inject 20 to $30 \mu \mathrm{L}$. Separate the digestion products using the following solvent program at a flow rate of $0.5 \mathrm{~mL} / \mathrm{min}$ :

a. isocratic elution with 1:99 (v/v) solvents B/A for $20 \mathrm{~min}$

b. linear gradient elution from 1:99 solvents B/A to 45:55 solvents B/A over 30 min

c. isocratic elution with 45:55 solvents B/A for $20 \mathrm{~min}$.

Typical retention times for various nucleotides are: $5^{\prime}-d C M P\left(\varepsilon_{260}=7,610\right), 9.7 \mathrm{~min}$; $5^{\prime}-T M P\left(\varepsilon_{260}=8,158\right), 27.3 \mathrm{~min} ; 5^{\prime}-d G M P\left(\varepsilon_{260}=9,969\right), 29.6 \mathrm{~min} ; 5^{\prime}-A M P\left(\varepsilon_{260}=\right.$ 12,300), $31.7 \mathrm{~min} ; 5^{\prime}-d A M P\left(\varepsilon_{260}=14,300\right), 41.2 \mathrm{~min} ; 5^{\prime}-p A 2^{\prime}-p\left(\mathrm{CH}_{2}\right)_{4} p\left(\mathrm{CH}_{2}\right)_{4} \mathrm{OH}$ $\left[A M P(p B u)_{2}\right]\left(\varepsilon_{260}=12,300\right), 39.5 \mathrm{~min}$. A typical chromatogram of a digestion is shown in Figure 4.4.4.

Synthesis and Characterization of Chimeric 2-5A-DNA Oligonucleotides

6. Normalize the absorbance of each peak by dividing by the extinction coefficient $\left(\varepsilon_{260}\right)$, and thereby ascertain the relative ratios of each nucleotide. 


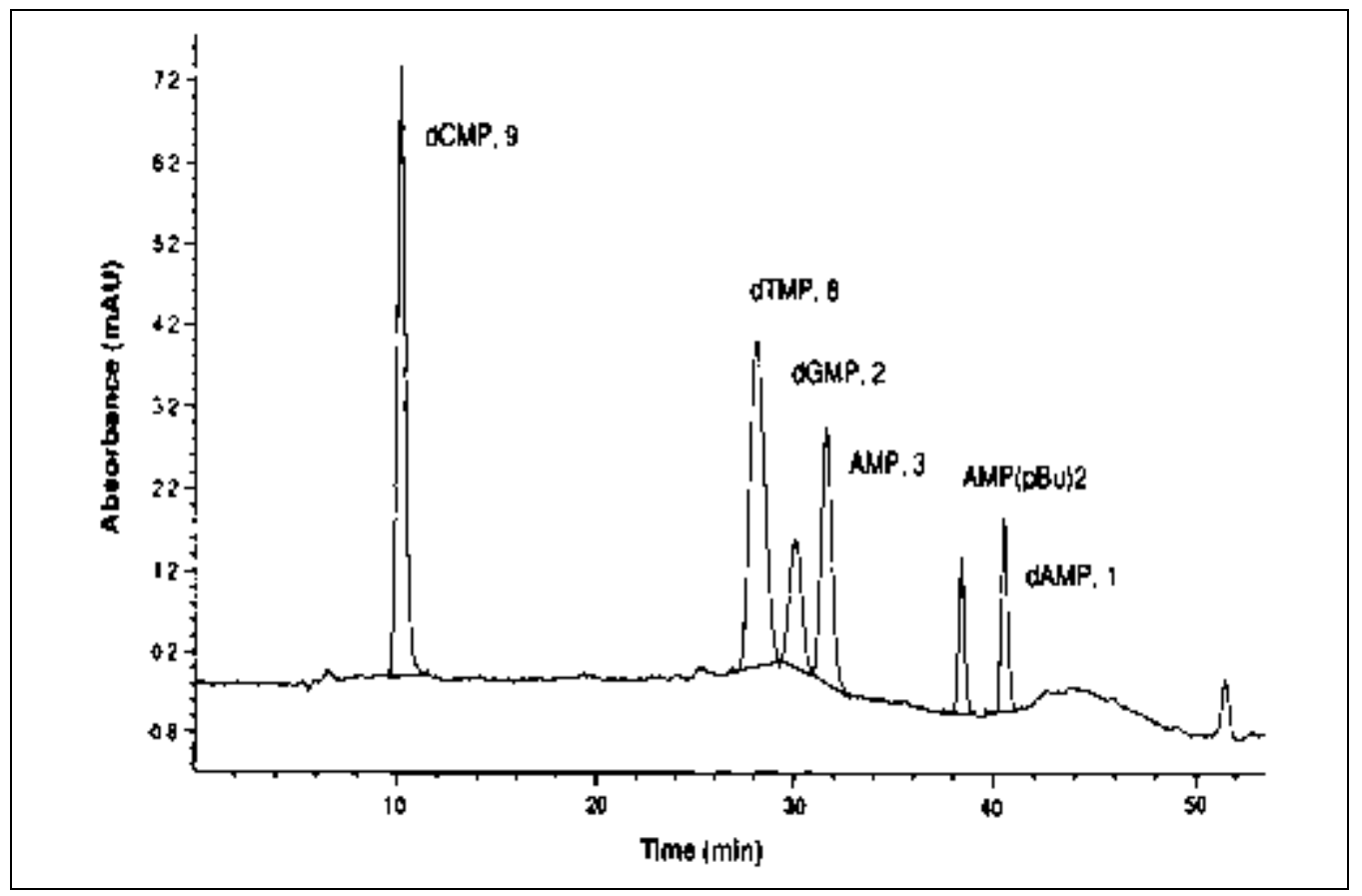

Figure 4.4.4 Digestion of a representative 2-5A-antisense chimera with snake venom phosphodiesterase and analysis by HPLC. A snake venom phosphodiesterase digest of the chimera $5^{\prime}-\mathrm{pA}\left(2^{\prime}, 5^{\prime}-\mathrm{pA}\right)_{3}-2^{\prime} \mathrm{p}\left[\left(\mathrm{CH}_{2}\right)_{4} \mathrm{p}\right]_{2} \mathrm{~d}[\mathrm{TCT}$ CCG CTT CTT CCT GCC AT] was injected into a $250 \times 4.6-\mathrm{mm}$ Beckman Ultrasphere C18 ODS column. Elution was with $2 \%$ solvent $B$ in $98 \%$ solvent $A$ isocratically for $20 \mathrm{~min}$, then a linear gradient of $2 \%$ to $50 \%$ solvent $B$ in solvent $A$ for $15 \mathrm{~min}$, then $50 \%$ solvent $B$ isocratically for 20 min. Solvent $A$ was $100 \mathrm{mM}$ ammonium phosphate, $\mathrm{pH} 5.5$, and solvent $B$ was $1: 1(\mathrm{v} / \mathrm{v})$ methanol $/ \mathrm{H}_{2} \mathrm{O}$. The flow rate was $0.5 \mathrm{~mL} / \mathrm{min}$ and detection was at $260 \mathrm{~nm}$.

\section{SEQUENCING CHIMERIC 2-5A-ANTISENSE OLIGONUCLEOTIDES ACCORDING TO A MODIFIED MAXAM-GILBERT PROCEDURE}

Although the size and unusual chemical structure of 2-5A-antisense chimeras do not permit enzymatic sequencing, the Maxam-Gilbert procedure can be employed if certain modifications are followed. In this procedure, the chimera is $3^{\prime}$-end labeled using $\left[\alpha{ }^{3}{ }^{32} \mathrm{P}\right] \mathrm{ddATP}$ and terminal nucleotide transferase.

\section{Materials}

Purified 2-5A-antisense chimera (see Basic Protocol 2)

$5 \times$ TNT buffer (see recipe)

$\left[\alpha-{ }^{32} \mathrm{P}\right] \mathrm{ddATP}(3000 \mathrm{Ci} / \mathrm{mmol}, 10 \mathrm{mCi} / \mathrm{mL}$; Amersham $)$

$15 \mathrm{U} / \mu \mathrm{L}$ terminal deoxyribonucleotide transferase (TNT) from calf thymus (Life Technologies)

0.5 M EDTA, pH 8 (APPENDIX 2A)

$1 \mathrm{mg} / \mathrm{mL}$ calf thymus DNA (Clontech)

$0.5 \mathrm{M}$ sodium phosphate buffer, $\mathrm{pH} 6.8$ (see recipe)

Scintillation fluid

Diethyl pyrocarbonate (DEPC; Sigma)

DEPC buffer (see recipe)

Ethanol

0.3 and $3 \mathrm{M}$ sodium acetate (Quality Biological), $\mathrm{pH}$ 6, in water

$4 \mathrm{mg} / \mathrm{mL}$ yeast tRNA (Clontech)

Dimethyl sulfate (DMS; Aldrich)

DMS buffer (see recipe)

DMS stop buffer (see recipe) 
$\mathrm{A}>\mathrm{C}$ buffer (see recipe)

$1 \mathrm{~N}$ acetic acid

Hydrazine (HZ; Aldrich)

HZ stop buffer (see recipe)

$5 \mathrm{M} \mathrm{NaCl}$ (Quality Biological) in water

$1 \mathrm{M}$ piperidine (Aldrich) in water, freshly prepared

Denaturing gel-loading buffer (see recipe)

10× TBE electrophoresis buffer (APPENDIX 2A)

Lyophilizer

ChromaSpin-10 gel column (Clontech)

Whatman DE81 filters

Vacuum manifold

Siliconized tubes

Heating blocks at $25^{\circ}, 60^{\circ}$, and $90^{\circ} \mathrm{C}$

Additional reagents and equipment for polyacrylamide gel electrophoresis (PAGE; APPENDIX 3B)

\section{3'-End label 2-5A-antisense chimera}

1. Lyophilize $10 \mathrm{pmol}$ of purified 2-5A-antisense chimera.

2. Add the following in order:

$10 \mu \mathrm{L} 5 \times$ TNT buffer

$32 \mu \mathrm{L} \mathrm{ddH}_{2} \mathrm{O}$

$6 \mu \mathrm{L}\left[\alpha-{ }^{32} \mathrm{P}\right] \operatorname{ddATP}(20 \mathrm{pmol})$

$2 \mu \mathrm{L} 15 \mathrm{U} / \mu \mathrm{L}$ TNT.

3. Incubate $60 \mathrm{~min}$ at $37^{\circ} \mathrm{C}$.

4. Stop reaction by adding $4 \mu \mathrm{L}$ of $0.5 \mathrm{M}$ EDTA, $\mathrm{pH} 8$, and $6 \mu \mathrm{L}$ of $1 \mathrm{mg} / \mathrm{mL}$ calf thymus DNA. Vortex gently.

5. Set aside $1 \mu \mathrm{L}$ for determination of specific activity (steps 8 to 11 ).

6. Apply the remainder of the reaction to a precentrifuged ChromaSpin-10 gel column and elute with water by centrifuging $6 \mathrm{~min}$ at $700 \times g$, at $4^{\circ} \mathrm{C}$.

7. Lyophilize eluted solution and store at $-20^{\circ} \mathrm{C}$ until use (up to 2 weeks).

\section{Determine specific activity of labeled chimera}

8. Dilute $1 \mu \mathrm{L}$ labeling reaction (from step 5) in $99 \mu \mathrm{L}$ of $0.2 \mathrm{M}$ EDTA, $\mathrm{pH} 8$.

9. Place quadruplicate $3-\mu \mathrm{L}$ spots of diluted sample on separate Whatman DE81 filters. Dry at $50^{\circ} \mathrm{C}$.

10. Wash two filters on a vacuum manifold with $30 \mathrm{~mL}$ of $0.5 \mathrm{M}$ sodium phosphate buffer, $\mathrm{pH} 6.8$, and dry them at $50^{\circ} \mathrm{C}$.

Washing will remove unincorporated nucleotide. The two unwashed filters are used to determine the total cpm in the sample.

Synthesis and Characterization of Chimeric 2-5A-DNA Oligonucleotides

11. Add scintillation fluid to each filter and count them in a liquid scintillation counter. Use the cpm from the filters to determine the following:

$$
\% \text { incorporation }=\mathrm{cpm} \text { incorporated } / \text { total } \mathrm{cpm}
$$


$\% 3^{\prime}$ ends labeled $=\%$ incorporation $\times 2$

specific activity $=\%$ incorporation $\times$ total $\mathrm{cpm}$ added to reaction $/ \mu \mathrm{g}$ chimera.

Expected values are $10 \%$ to $15 \%$ incorporation, with $20 \%$ to $30 \%$ of $3^{\prime}$ ends labeled, and specific activity of $\sim 10^{8} \mathrm{cpm} / \mu \mathrm{g}$ chimera.

\section{Perform sequencing reactions}

12. Set up rA reaction to cleave primarily at riboadenosine residues:

a. Place a siliconized tube containing $1 / 6$ of the labeled chimera on ice.

b. Add $150 \mu \mathrm{L}$ DEPC buffer followed by $2 \mu \mathrm{L}$ of 1:9 (v/v) DEPC/ethanol.

c. Vortex and incubate $5 \mathrm{~min}$ at $90^{\circ} \mathrm{C}$.

d. Add $15 \mu \mathrm{L}$ of $3 \mathrm{M}$ sodium acetate, $\mathrm{pH} 6$.

e. Add $5 \mu \mathrm{L}$ of $4 \mathrm{mg} / \mathrm{mL}$ yeast tRNA and $800 \mu \mathrm{L}$ ethanol.

f. Vortex and bring to $-70^{\circ} \mathrm{C}$.

13. Set up $G$ reaction for primary cleavage at deoxyguanosine and minor cleavage at riboadenosine.

a. Place a siliconized tube containing $1 / 6$ of the labeled chimera on ice.

b. Add $200 \mu \mathrm{L}$ DMS buffer followed by $1 \mu \mathrm{L}$ dimethyl sulfate.

c. Vortex and incubate $20 \mathrm{~min}$ at $25^{\circ} \mathrm{C}$.

d. Add $50 \mu \mathrm{L}$ DMS stop buffer and $800 \mu \mathrm{L}$ ethanol.

e. Vortex and bring to $-70^{\circ} \mathrm{C}$.

14. Set up $A>C$ reaction for cleavage primarily at deoxyadenosine, with secondary cleavage at deoxycytidine and riboadenosine.

a. Place a siliconized tube containing $1 / 6$ of the labeled chimera on ice.

b. Add $100 \mu \mathrm{L} \mathrm{A}>\mathrm{C}$ buffer.

c. Vortex and incubate $15 \mathrm{~min}$ at $90^{\circ} \mathrm{C}$.

d. Add $150 \mu \mathrm{L}$ of $1 \mathrm{~N}$ acetic acid, $5 \mu \mathrm{L}$ of $4 \mathrm{mg} / \mathrm{mL}$ yeast tRNA, and $800 \mu \mathrm{L}$ ethanol.

e. Vortex and bring to $-70^{\circ} \mathrm{C}$.

15. Set up $A+G$ reaction for cleavage at riboadenosine, deoxyadenosine, and deoxyguanosine.

a. Place a siliconized tube containing $1 / 6$ of the labeled chimera on ice.

b. Add $150 \mu \mathrm{L}$ DEPC buffer followed by $2 \mu \mathrm{L}$ of 1:9 (v/v) DEPC/ethanol.

c. Vortex and incubate $5 \mathrm{~min}$ at $90^{\circ} \mathrm{C}$.

d. Add $15 \mu \mathrm{L}$ of $3 \mathrm{M}$ sodium acetate, $\mathrm{pH} 6$.

e. Add $5 \mu \mathrm{L}$ of $4 \mathrm{mg} / \mathrm{mL}$ yeast tRNA and $800 \mu \mathrm{L}$ ethanol.

f. Vortex and bring to $-70^{\circ} \mathrm{C}$.

16. Set up $\mathrm{T}+\mathrm{C}$ reaction for cleavage at deoxythymidine, deoxycytidine, and riboadenosine.

a. Place a siliconized tube containing $1 / 6$ of the labeled chimera on ice.

b. Add $15 \mu \mathrm{L}$ water followed by $30 \mu \mathrm{L}$ hydrazine.

c. Vortex and incubate $60 \mathrm{~min}$ at $25^{\circ} \mathrm{C}$.

d. Add $400 \mu \mathrm{L} \mathrm{HZ}$ stop buffer and $800 \mu \mathrm{L}$ ethanol.

e. Vortex and bring to $-70^{\circ} \mathrm{C}$.

17. Set up $\mathrm{C}$ reaction for strong cleavage at deoxycytidine and riboadenosine.

Synthesis of Modified Oligonucleotides and Conjugates 

a. Place a siliconized tube containing $1 / 6$ of the labeled chimera on ice.
b. Add $15 \mu \mathrm{L}$ of $5 \mathrm{M} \mathrm{NaCl}$ followed by $30 \mu \mathrm{L}$ hydrazine.
c. Vortex and incubate $60 \mathrm{~min}$ at $25^{\circ} \mathrm{C}$.
d. Add $400 \mu \mathrm{L} \mathrm{HZ}$ stop buffer and $800 \mu \mathrm{L}$ ethanol.
e. Vortex and bring to $-70^{\circ} \mathrm{C}$.

\section{Wash all samples}

18. Centrifuge $15 \mathrm{~min}$ at $12,000 \times g, 4^{\circ} \mathrm{C}$.

19. Withdraw and discard supernatant, checking with a survey meter that very little labeled chimera is removed.

20. Redissolve chimera in $400 \mu \mathrm{L}$ of $0.3 \mathrm{M}$ sodium acetate, $\mathrm{pH} 6$.

21. Add $800 \mu \mathrm{L}$ ethanol, vortex, bring to $-70^{\circ} \mathrm{C}$, and centrifuge $15 \mathrm{~min}$ at $12,000 \times g$, $4^{\circ} \mathrm{C}$.

22. Repeat steps 19 and 21 (do not add sodium acetate).

23. Remove most of the supernatant and lyophilize pellet for $15 \mathrm{~min}$.

\section{Cleave modified bases with piperidine}

24. Add $100 \mu \mathrm{L}$ of $1 \mathrm{M}$ piperidine to DNA samples and vortex.

25. Make sure lids are securely shut and incubate $20 \mathrm{~min}$ at $60^{\circ} \mathrm{C}$ (for $\mathrm{rA}$ reaction) or 30 min at $90^{\circ} \mathrm{C}$ (for all other reactions).

26. Cool on ice and lyophilize for $15 \mathrm{~min}$.

27. Add $15 \mu \mathrm{L}$ water, vortex, and lyophilize again. Repeat.

\section{Perform polyacrylamide gel electrophoresis (PAGE)}

28. Add $100 \mu \mathrm{L}$ denaturing gel-loading buffer.

29. Denature samples $60 \mathrm{~min}$ at $90^{\circ} \mathrm{C}$ and then cool on ice.

30. Pour and set up $20 \%$ polyacrylamide/8 M urea sequencing gel (see APPENDIX $3 B$ ) using $1 \times$ TBE electrophoresis buffer and pre-run for $2 \mathrm{hr}$ at $130 \mathrm{~W}$ constant power.

Gel will heat to $55^{\circ} \mathrm{C}$.

31. Load samples and run at $130 \mathrm{~W}$ constant power until the bromphenol blue has migrated $\sim 19 \mathrm{~cm}$ down from the wells. Remove one or both plates.

32. Mark the upper left corner of the gel with radioactive ink and autoradiograph. A typical result is shown in Figure 4.4.5.

\section{REAGENTS AND SOLUTIONS}

Use deionized, distilled water in all recipes and protocol steps. For common stock solutions, see APPENDIX 2A; for suppliers, see SUPPLIERS APPENDIX.

\section{$A>C$ buffer}

$0.480 \mathrm{mg}$ sodium hydroxide $(1.2 \mathrm{~N})$

$20 \mu \mathrm{L} 1 \mathrm{mM}$ EDTA

$\mathrm{H}_{2} \mathrm{O}$ to $10 \mathrm{~mL}$

Synthesis and Characterization of Chimeric 2-5A-DNA Oligonucleotides

\section{Aniline solution, $1 \mathrm{M}, \mathrm{pH} 4.5$}

$931 \mu \mathrm{L}$ aniline (Aldrich)

$8.869 \mathrm{~mL} \mathrm{H}_{2} \mathrm{O}$ 


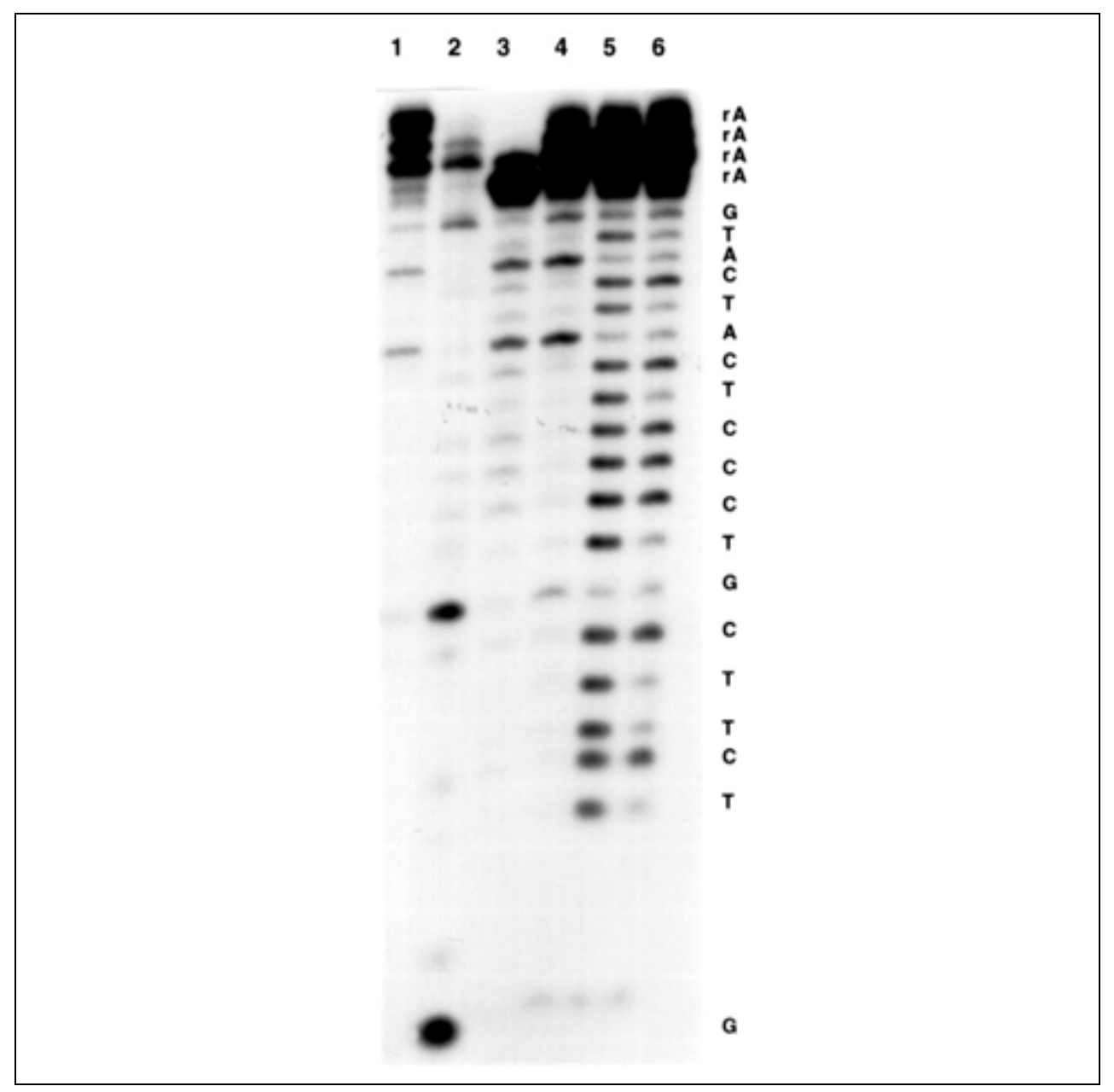

Figure 4.4.5. Maxam-Gilbert sequencing of the $2-5 A$-antisense chimera $5^{\prime}-\mathrm{pA}\left(2^{\prime}, 5^{\prime}-\mathrm{pA}\right)_{3}-2^{\prime}-$ $\mathrm{p}\left[\left(\mathrm{CH}_{2}\right)_{4} \mathrm{p}\right]_{2} \mathrm{~d}[\mathrm{TCT}$ CCG CTT CTT CCT GCC AT]. Lane 1, rA; lane 2, G; lane 3, A>C; lane 4, A+G; lane $5, \mathrm{~T}+\mathrm{C}$; lane $6, \mathrm{C}$.

Adjust $\mathrm{pH}$ to 4.5 with acetic acid

Store in the dark at $-20^{\circ} \mathrm{C}$

Precipitate will clear upon addition of acetic acid.

\section{ATP/dTTP stock solution}

$4.8 \mathrm{mg}$ dTTP (final $1.0 \mathrm{mM}$ )

$0.55 \mathrm{mg}$ ATP (final $0.1 \mathrm{mM}$ )

Adjust $\mathrm{pH}$ to 7.0

Add $\mathrm{H}_{2} \mathrm{O}$ to $10.0 \mathrm{~mL}$

\section{Denaturing gel-loading buffer}

$8 \mathrm{~mL}$ formamide (Fluka; $80 \% \mathrm{v} / \mathrm{v}$ )

$1 \mathrm{~g}$ sucrose $(10 \% \mathrm{w} / \mathrm{v})$

$40 \mu \mathrm{L} 2 \mathrm{mM}$ EDTA

$0.2 \%(\mathrm{w} / \mathrm{v})$ bromphenol blue (Sigma)

Add $\mathrm{H}_{2} \mathrm{O}$ to $10 \mathrm{~mL}$

\section{Diethyl pyrocarbonate (DEPC) buffer}

$166 \mu \mathrm{L} 3 \mathrm{M}$ sodium acetate, $\mathrm{pH} 6$ (final $50 \mathrm{mM}, \mathrm{pH}$ 5)

$20 \mu \mathrm{L} 0.5 \mathrm{M}$ EDTA (final $1 \mathrm{mM}$ )

$\mathrm{H}_{2} \mathrm{O}$ to $10 \mathrm{~mL}$

Synthesis of 
Dimethyl sulfate (DMS) buffer

$80 \mathrm{mg}$ sodium cacodylate (Aldrich), $\mathrm{pH} 8.0$ (final $50 \mathrm{mM}$ )

$20 \mu \mathrm{L} 1 \mathrm{mM}$ EDTA

$\mathrm{H}_{2} \mathrm{O}$ to $10 \mathrm{~mL}$

\section{DMS stop buffer}

$829 \mu \mathrm{L} 1.5 \mathrm{M}$ sodium acetate, $\mathrm{pH} 7.0$

$71 \mu \mathrm{L} 1 \mathrm{M} 2$-mercaptoethanol

$25 \mu \mathrm{L} 100 \mu \mathrm{g} / \mathrm{mL}$ yeast tRNA

$75 \mu \mathrm{L} \mathrm{H} \mathrm{H}_{2} \mathrm{O}$

Prepare fresh before use

\section{Hydrazine (HZ) stop buffer}

$400 \mu \mathrm{L} 1.5 \mathrm{M}$ sodium acetate, $\mathrm{pH} 7$ (final $0.3 \mathrm{M}$ )

$200 \mu \mathrm{L} 1 \mathrm{mM}$ EDTA (final $0.1 \mathrm{mM}$ )

$15 \mu \mathrm{L} 25 \mu \mathrm{g} / \mathrm{mL}$ yeast tRNA (final $0.2 \mu \mathrm{g} / \mathrm{mL}$ )

$\mathrm{H}_{2} \mathrm{O}$ to $2 \mathrm{~mL}$

Prepare fresh before use

\section{Phosphoramidite solutions, $0.1 \mathrm{M}$}

Dry phosphoramidites over anhydrous $\mathrm{P}_{2} \mathrm{O}_{5}$ for $\geq 33 \mathrm{hr}$. Dilute in anhydrous acetonitrile to make each $0.1 \mathrm{M}$ solution (see Table 4.4.3). Use within a week.

\section{Sodium phosphate buffer, $0.5 \mathrm{M}, \mathrm{pH} 6.8$}
$4.73 \mathrm{~g} \mathrm{NaH}_{2} \mathrm{PO}_{4}$
$2.24 \mathrm{~g} \mathrm{Na}_{2} \mathrm{HPO}_{4}$
$\mathrm{H}_{2} \mathrm{O}$ to $100 \mathrm{~mL}$

Terminal deoxyribonucleotide transferase (TNT) buffer, $5 \times$

$500 \mathrm{mM}$ potassium cacodylate

$1 \mathrm{mM}$ dithiothreitol

$10 \mathrm{mM} \mathrm{CoCl}_{2}$

Adjust $\mathrm{pH}$ to 7.2

\section{COMMENTARY}

\section{Background Information}

The 2-5A system (Johnston and Torrence, 1984; Player and Torrence, 1998) has been the basis of a targeted mRNA destruction method that derives from the covalent linkage of a $\left(3^{\prime}-5^{\prime}\right)$-antisense oligodeoxyribonucleotide and a $\left(2^{\prime}-5^{\prime}\right)$-oligoadenylate activator of RNase $\mathrm{L}$, the 2-5A-dependent RNase (Lesiak et al., 1993; Torrence et al., 1993). This composite nucleic acid (Fig. 4.4.1; Xiao et al., 1996) could, through the antisense domain, target the chimera to a particular mRNA sequence, which
Synthesis and Characterization of Chimeric 2-5A-DNA Oligonucleotides

Table 4.4.3 Preparation of Automated Synthesizer Reagents

\begin{tabular}{lllll}
\hline CE phosphoramidite & $\begin{array}{l}\mathrm{CH}_{3} \mathrm{CN} \\
(\mathrm{mL})\end{array}$ & $\begin{array}{l}\text { Molarity } \\
(\mathrm{M})\end{array}$ & $\begin{array}{l}\text { Coupling } \\
\text { cycles }\end{array}$ & Sources \\
\hline $500 \mathrm{mg} \mathrm{dA}^{\mathrm{Bz}}$ & 5.6 & 0.1 & 25 & PE Biosystems \\
$500 \mathrm{mg} \mathrm{dG}^{i-\mathrm{Bu}}$ & 5.8 & 0.1 & 24 & PE Biosystems \\
$500 \mathrm{mg} \mathrm{dC}$ Bz & 5.9 & 0.1 & 24 & PE Biosystems \\
$500 \mathrm{mg} \mathrm{T}$ & 6.6 & 0.1 & 27 & PE Biosystems \\
$0.25 \mathrm{~g}$ butanediol linker & 3.75 & 0.1 & 10 & Support Protocol 2 \\
$500 \mathrm{mg} \mathrm{2-5A}$ & 5.0 & 0.1 & 24 & Support Protocol 1 \\
$0.25 \mathrm{~g}$ phosphorylation reagent & 3.8 & 0.1 & 7 & Glen Research \\
\hline
\end{tabular}


would then be targeted for destruction by the 2-5A component via a localized activation of the latent 2-5A-dependent RNase.

The prototype 2-5A-antisense chimera consisted of an antisense domain made up of oligo(dT $)_{18}$ connected to $2-5 \mathrm{~A}$ through a linker (Lesiak et al., 1993; Torrence et al., 1993). The 2-5A and antisense moieties were joined together through phosphodiester bonds and two 1,4-butanediol molecules linked to each other by a phosphodiester function. Linkage to the 2-5A tetramer was at the 2 '-terminal hydroxyl, and linkage to the antisense oligonucleotide was at the 5'-terminal hydroxyl. The mode of linkage to the 2-5A component was through the $2^{\prime}$ terminus of the oligomer, since a free $5^{\prime}$-monophosphate was required for maximal 2-5Adependent endonuclease activity (Johnston and Torrence, 1984; Player and Torrence, 1998). Linker elements were used to join 2-5A to the antisense DNA sequence rather than directly joining the terminal 2-5A adenosine nucleotide to the first nucleotide of the antisense sequence. Such a strategy was used because of the possibility that RNase L, once bound to the $2-5 \mathrm{~A}$ component of the chimera, might disturb hybridization to target RNA, or conversely that the double helix generated by the antisense oligonucleotide and the sense RNA might interfere with binding to RNase $\mathrm{L}$.

The 2-5A antisense approach has led to sequence-specific cleavage of a modified human immunodeficiency virus RNA (Torrence et al., 1993) and of mRNA encoding the dsRNA-dependent protein kinase (PKR) in cell-free systems (Maitra et al., 1995), as well as ablation in intact HeLa cells of PKR mRNA, PKR protein, and the biological function of PKR (Maran et al., 1994). In addition, respiratory syncytial virus (RSV) replication has been inhibited by specific 2-5A-antisense targeting of the RSV M2 mRNA (Cirino et al., 1997).

The actual chemical synthesis of 2-5A-antisense oligonucleotides involves the solid-support phosphite-triester approach to DNA/RNA synthesis (e.g., Beaucage and Caruthers, 1981). Appropriately protected 2-cyanoethylphosphoramidite derivatives of the riboadenosine, butanediol linker, and the usual four deoxyribonucleosides are used for chain elongation. Sugar protection consists of the usual 4,4'-dimethoxytrityl for $5^{\prime}$ hydroxyls and tert-butyldimethylsilyl for $2^{\prime}$ or $3^{\prime}$ hydroxyls. For base protection, $\mathrm{A}^{\mathrm{Bz}}, \mathrm{C}^{\mathrm{Bz}}$, and $\mathrm{G}^{i-\mathrm{Bu}}$ have been used by this laboratory for some time with good success; however, the authors have used commercially available $\mathrm{A}^{\mathrm{PAC}}, \mathrm{C}^{i-\mathrm{Bu}}$, and $\mathrm{G}^{\mathrm{PAC}}$, which allow faster ammoniacal workup and yield slightly cleaner crude product. 2-Cyanoethylphosphoramidites are the functionality of choice for phosphodiester bond generation.

The following generic oligonucleotide structural types are described in this unit:

I: $5^{\prime}-\mathrm{pA}\left(2^{\prime}, 5^{\prime}-\mathrm{pA}\right)_{3}-2^{\prime}-\mathrm{p}\left[\left(\mathrm{CH}_{2}\right)_{4} \mathrm{p}\right]_{2} \mathrm{dN}\left(3^{\prime}, 5^{\prime}-\right.$ $\mathrm{pdN})_{n}$

II: $5^{\prime}$-pA $\left(2^{\prime}, 5^{\prime}-\mathrm{pA}\right)_{3}{ }^{-} 2^{\prime}-\mathrm{p}\left[\left(\mathrm{CH}_{2}\right)_{4} \mathrm{p}\right]_{2} \mathrm{dN}\left(3^{\prime}, 5^{\prime}-\right.$ $\mathrm{pdN})_{m}\left(3^{\prime}, 3^{\prime}-\mathrm{pdN}\right)$

Analytical results are somewhat different when the snake venom phosphodiesterase protocol is applied to a type II ( $\mathrm{Li}$ et al., 1997) $2-5 A$-antisense chimera. Specifically, a (3'-3')dinucleotide $5^{\prime}$-monophosphate derived from the last two nucleotides of the chimera's $3^{\prime}$ terminus is produced. Structural information to corroborate the identity of the dinucleotide can be obtained by comparing their HPLC on-line UV spectra with the calculated spectra of the $1: 1$ summation of constituent mononucleotides. Finally, the structure of the $\left(3^{\prime}-3^{\prime}\right)$ dinucleotide fragment can be corroborated by comparing the HPLC chromatogram of the enzymatically digested product with that of a synthetic dinucleotide produced by a DNA synthesizer using a nucleoside bound to $\mathrm{CPG}$ through the 5'-hydroxyl group.

The retention times of the $\left(3^{\prime}-3^{\prime}\right)$-dinucleotide products vary depending upon their composition and, in some cases, can interfere with other peaks in the HPLC analysis of snake venom phosphodiesterase digests. Under these conditions, accurate analysis of these key digestion products can be problematic. In order to obviate this difficulty, digestion with snake venom phosphodiesterase can be carried out with the addition of bacterial alkaline phosphatase. This results in the removal of all noninternucleotide phosphates, so that digestion products consist of nucleosides and the ( $\left.3^{\prime}-3^{\prime}\right)$ dinucleotide. Thus, this modified digestion procedure can result in a shift in retention times $\left(R_{\mathrm{t}}\right)$ such that each individual product is well separated from the others. This additional digestion procedure is not always necessary; its necessity depends on the composition of the dinucleotide product. Many ( $\left.3^{\prime}-3^{\prime}\right)$-dinucleotides can be resolved very well from all nucleotides, and can be easily identified by their on-line UV spectra and subsequently integrated.

In general, the syntheses follow the strategies developed in Lesiak et al. (1993), Xiao et al. (1996), and Li et al. (1997). Type I 2-5A-antisense chimeras were the first structural type
Synthesis of Modified Oligonucleotides and Conjugates

\subsubsection{1}

Supplement 1 
synthesized (Lesiak et al., 1993; Torrence et al., 1993) and were used with success in cell-free systems and in intact cells (Torrence et al., 1993; Maran et al., 1994; Maitra et al., 1995). Type II 2-5A-antisense chimeras with 3 '-terminally inverted phosphodiester bonds have proven to be of greater stability toward exonuclease degradation and have been exploited to block respiratory syncytial virus replication (Cirino et al., 1997).

\section{Critical Parameters}

In the prototypical $2-5 \mathrm{~A}$ antisense chimera, 2-5A and antisense DNA were joined through two linkers of 1,4-butanediol phosphate that arise from the key intermediate $4-O-\left(4,4^{\prime}\right.$ dimethoxytrityl)oxybutyl-1-[(2-cyanoethyl)$N, N$-diisopropylphosphoramidite]. The yield of this intermediate is improved significantly when using 2:10:1 (v/v) ethyl acetate/hexane/triethylamine as the flash purification chromatography solvent. Triethylamine in the purification may prevent decomposition of this acid-sensitive compound during exposure to silica gel.

Key considerations in the characterization of 2-5A-antisense chimeras include: (1) that $\left(2^{\prime}, 5^{\prime}\right)$-phosphodiester bonds in the RNA portion of the chimera are not isomerized to $\left(3^{\prime}, 5^{\prime}\right)$ phosphodiesters during or after synthesis; (2) that 1,4-butanediol phosphate linker connects 2-5A and antisense DNA in the anticipated position; and (3) that phosphorylation does, in fact, occur at the $5^{\prime}$ terminus in high yield. Approaches to address these questions may be found in Xiao et al. (1996).

\section{Anticipated Results}

Under the conditions described herein, the coupling efficiencies for different regions of the 2-5A-antisense molecule should be: antisense DNA, $98 \%$ to $99 \%$; butanediol linkers, $97 \%$ to 98\%; (2',5')-RNA, $94 \%$ to $98 \%$; and phosphorylation, $98 \%$ to $99 \%$. The average stepwise coupling yield for 2-5A-antisense chimera should be $96 \%$ to $98 \%$.

When 2-5A-antisense oligonucleotides are synthesized and purified according to the procedures outlined herein, products of purities approaching $95 \%$ are possible. Isolated yields of purified chimeric oligonucleotides of $70 A_{260}$ units are achievable.

The digestion of a representative 2-5A-antisense chimera with snake venom phosphodiesterase is shown in Figure 4.4.4. This HPLC picture of the snake venom digestion differs when the substrate for digestion contains a $\left(3^{\prime}-3^{\prime}\right)$-phosphodiester-linked dinucleotide. When a representative $\left(3^{\prime}-3^{\prime}\right)$-tailed chimera, $5^{\prime}$-pA $\left(2^{\prime} 5^{\prime}-\mathrm{pA}\right)_{3}-2^{\prime} \mathrm{p}(\text { Bup })_{2}$-pd [AAT GGG ATC CAT TTT GTC C $\left.\left(3^{\prime}-3^{\prime}\right) \mathrm{C}\right]$, is digested under standard conditions with snake venom phosphodiesterase, the HPLC of digestion products will reveal seven major peaks with retention times of 10.8, 29.2, 31.1, 32.59, 39.3, 40.2 , and $41.5 \mathrm{~min}$. The first five correspond to, respectively, dCMP, dTMP, dGMP, rAMP, and $\mathrm{AMP}(\mathrm{pBu})_{2}$. At $40.2 \mathrm{~min}$, a new product appears that is not observed in a similar digestion of a standard first-generation 2-5A-antisense chimera with no $3^{\prime}-3^{\prime}$ linkage. Lastly, $\mathrm{dAMP}$ is at $41.5 \mathrm{~min}$. The overall ratio of above nucleotidic digestion products is $3: 7: 4: 3: 4$ for $\mathrm{dCMP} / \mathrm{dTMP} / \mathrm{dGMP} / \mathrm{rAMP} / \mathrm{dAMP}$, revealing an underabundance of dCMP from what would be expected from complete digestion. However, the peak with retention time of $40.2 \mathrm{~min}$ possessed a UV spectrum that could be generated by $1: 1$ addition of the spectra of two mononucleotides, $2 \times \mathrm{dCMP}$. Thus, the structure $\mathrm{pdC} 3^{\prime} \mathrm{p} 3^{\prime} \mathrm{dC}$ can be assigned to this new peak. The structure of this product $\left(3^{\prime}-3^{\prime}\right)$-dinucleotide can be corroborated by comparison of the HPLC chromatogram of enzymatically digested product with synthetic dinucleotide.

Similar HPLC digestion patterns were obtained when other $\left(3^{\prime}-3^{\prime}\right)$-tailed chimeras were digested with snake venom phosphodiesterase. For instance, $\mathrm{pA}_{4}-[\mathrm{pBu}]_{2}-\mathrm{pd}[\mathrm{GCC}$ CAC CGG GTC CAC CAT $\left.\left(3^{\prime}-3^{\prime}\right) \mathrm{C}\right]$ gave the dinucleotide pdT3'p3'dC $\left(R_{\mathrm{t}}=46.0 \mathrm{~min}\right)$ and $\mathrm{pA}_{4}-[\mathrm{pBu}]_{2^{-}}$ pd[TGG GAA GCT GTC ACT GTA GAG(3'$\left.\left.3^{\prime}\right) \mathrm{C}\right]$ yielded pdG3'p3'dC $\left(R_{\mathrm{t}}=44.4 \mathrm{~min}\right)$. The $\left(3^{\prime}-3^{\prime}\right)$-dinucleotides can be assigned structures based on a comparison of their UV spectra with the calculated spectra from 1:1 summation of constituent mononucleotides.

The retention times of the $\left(3^{\prime}-3^{\prime}\right)$-dinucleotide products varied depending upon their composition. For instance, the retention time of $\mathrm{pdC}^{\prime} \mathrm{p3}^{\prime} \mathrm{dC}$ is close to that of other digestion products such as dAMP $\left(R_{\mathrm{t}}=41.5 \mathrm{~min}\right)$ or $\mathrm{AMP}(\mathrm{pBu})_{2}\left(R_{\mathrm{t}}=40.2 \mathrm{~min}\right)$. Under these conditions, accurate analysis of these key digestion products may be problematic. To deal with this difficulty, digestion with snake venom phosphodiesterase can be carried out with the addition of bacterial alkaline phosphatase. This results in the removal of all non-internucleotide phosphates, so that digestion products consist of nucleosides and the (3'-3')-dinucleotide. Thus, for instance, when the chimera $5^{\prime}$ $\mathrm{pA}\left(2^{\prime}, 5^{\prime}-\mathrm{pA}\right)_{3}-2^{\prime}-(\mathrm{pBu})_{2}$-pd[AAT GGG ATC CAT TTT GTC $\left.\mathrm{C}\left(3^{\prime}-3^{\prime}\right) \mathrm{C}\right]$ is digested with 
snake venom phosphodiesterase and bacterial alkaline phosphatase, the following products are obtained: $\mathrm{dC}\left(R_{\mathrm{t}}=25.6 \mathrm{~min}\right), \mathrm{dG}\left(R_{\mathrm{t}}=42.8\right.$ $\min ), \mathrm{dT}\left(R_{\mathrm{t}}=44.8 \mathrm{~min}\right), \mathrm{dC} 3^{\prime} \mathrm{p} 3^{\prime} \mathrm{dC}\left(R_{\mathrm{t}}=47.8\right.$ $\min ), \mathrm{rA}\left(R_{\mathrm{t}}=50.1 \mathrm{~min}\right), \mathrm{dA}\left(R_{\mathrm{t}}=51.8 \mathrm{~min}\right)$, and $\mathrm{A} 2$ ' $\mathrm{pBupBu}\left(R_{\mathrm{t}}=54.9\right)$. Thus, this modified digestion procedure resulted in a shift in $R_{\mathrm{t}}$ values such that each individual product was well separated from the others. This additional digestion procedure is not always necessary, and its use depends on the constitution of the dinucleotide product.

\section{Time Considerations}

The following are estimations of the time needed for various stages of the synthesis, purification, and characterization of a chimeric 2-5A-antisense oligonucleotide.

Support Protocol 1 requires 6 days for synthesis of $N^{6}$-benzoyl-5' $-O$-dimethoxytrityl- $3^{\prime}$ $O$-tert-butyldimethylsilyladenosine- $2^{\prime}-N, N$ diisopropylphosphoramidite. Support Protocol 2 requires 2 days for synthesis of 4-O(4,4'-dimethoxytrityl)oxybutyl-1-[(2-cyanoethyl)- $N, N$-diisopropylphosphoramidite.

Basic Protocol 1 requires 6 to $8 \mathrm{hr}$ for automated 2-5A-antisense chimera synthesis on an ABI 391 or 392 synthesizer, and $3 \mathrm{hr}$ to overnight for cleavage and deprotection of the chimera.

Basic Protocol 2 requires $6 \mathrm{hr}$ for purification of the chimera by polystyrene reversedphase ion-pair HPLC; $6 \mathrm{hr}$ for desalting and concentration of the chimera; $3 \mathrm{hr}$ for cation exchange; 24 to $48 \mathrm{hr}$ for dialysis and sterilization; $12 \mathrm{hr}$ for capillary gel electrophosesis (a large number of samples may be run in this time when using an autosampler); and $4 \mathrm{hr}$ for the Dionex HPLC purity check.

Basic Protocol 3 requires 6 to $8 \mathrm{hr}$ for snake venom digestion and HPLC analysis of three samples.

Basic Protocol 4 requires $4 \mathrm{hr}$ for labeling the chimera with terminal nucleotide transferase; $4 \mathrm{hr}$ for determining the specific activity of the radioactive chimera; 6 to $8 \mathrm{hr}$ for MaxamGilbert sequencing; plus the necessary time for autoradiograph exposure.

\section{Literature Cited}

Beaucage, S.L. and Caruthers, M.H. 1981. Deoxyribonucleotide phosphoramidites-A new class of key intermediates for deoxypolynucleotide synthesis. Tetrahedron Lett. 22:1859-1862.

Cirino, N.M., Li, G., Xiao, W., Torrence. P.F., and Silverman, R.H. 1997. Targeting RNA for decay in respiratory syncytial virus infected cells with $2^{\prime} \rightarrow 5^{\prime}$ oligoadenylate antisense. Proc. Natl. Acad. Sci. U.S.A. 94:1937-1942.

Johnston, M.I. and Torrence, P.F. 1984. The role of interferon-induced proteins, double-stranded RNA and $2^{\prime}, 5^{\prime}$-oligoadenylate in the interferonmediated inhibition of viral translation. In Interferon: Mechanism of Production and Action (R.M. Freidman, ed.) pp. 189-298. Elsevier/ North-Holland, Amsterdam.

Lesiak, K., Khamnei, S., and Torrence, P.F. 1993. 2',5'-Oligoadenylate:antisense chimeras-Synthesis and properties. Bioconjugate Chem. 4:467-472.

Li, G., Xiao, W., and Torrence, P.F. 1997. Synthesis and properties of second generation 2-5A-antisense chimeras with enhanced resistance to exonucleases. J. Med. Chem. 40:2959-2966.

Maitra, R.K., Li, G., Xiao, W., Dong, B., Torrence, P., and Silverman, R.H. 1995. Catalytic cleavage of an RNA target by 2-5A antisense and RNase L. J. Biol. Chem. 270:15071-15075.

Maran, A., Maitra, R.K., Kumar, A., Dong, B., Xiao, W., Li, G., Williams, B.R.G., Torrence, P.F., and Silverman, R.H. 1994. Blockage of NF-kB signaling by selective ablation of an mRNA target by 2-5A antisense chimeras. Science 265:789792.

Player, M. and Torrence, P.F. 1998. The 2-5A system: Modulation of viral and cellular processes through acceleration of RNA degradation. Pharmacol. Therapeut. 78:55-113.

Torrence, P.F., Maitra, R.K., Lesiak, K., Khamnei, S., Zhou, A., and Silverman, R.H. 1993. Targeting RNA for degradation with a $\left(2^{\prime}-5^{\prime}\right)$ oligoadenylate-antisense chimera. Proc. Natl. Acad. Sci. U.S.A. 90:1300-1304.

Xiao, W., Player, M.R., Li, G., Zhang, K., Lesiak, K., and Torrence, P.F. 1996. Synthesis and characterization of composite nucleic acids containing $2^{\prime}, 5^{\prime}$-oligoriboadenylate linked to antisense DNA. Antisense Nucleic Acid Drug Devel. $6: 247-258$

Contributed by Mark R. Player and

Paul F. Torrence

Northern Arizona University

Flagstaff, Arizona
Synthesis of Modified Oligonucleotides and Conjugates

\subsubsection{3}

Supplement 1 